\title{
Impact of the antidepressant citalopram on the behaviour of two different life stages of brown trout
}

\author{
Michael Ziegler ${ }^{\text {Corresp., }}{ }^{\text {, }}$ Sarah Knoll ${ }^{2}$, Heinz R. Köhler ${ }^{1}$, Selina Tisler ${ }^{3}$, Carolin Huhn ${ }^{2}$, Christian Zwiener $^{3}$, Rita \\ Triebskorn ${ }^{1,4}$ \\ ${ }^{1}$ Animal Physiolgical Ecology, Eberhard-Karls-Universität Tübingen, Tübingen, Baden-Württemberg, Germany \\ Effect-based Environmental Analysis, Eberhard-Karls-Universität Tübingen, Tübingen, Baden-Württemberg, Germany \\ 3 Environmental Analytical Chemistry, Eberhard-Karls-Universität Tübingen, Tübingen, Baden-Württemberg, Germany \\ 4 Steinbeis Transfer Center for Ecotoxicology and Ecophysiology, Rottenburg, Baden-Württemberg, Germany \\ Corresponding Author: Michael Ziegler \\ Email address: michael.ziegler@student.uni-tuebignen.de
}

Background. Over the last two decades, there has been a constant increase in prescription rates of antidepressants. In parallel, neuroactive pharmaceuticals are making their way into aquatic environments at increasing concentrations. Among the antidepressants detected in the environment citalopram, a selective serotonin reuptake inhibitor, is one of the most commonly found. Given citalopram is specifically designed to alter mood and behaviour in humans, there is growing concern it can adversely affect the behaviour on non-target wildlife

Methods. In our study, brown trout were exposed to citalopram (nominal concentrations: 1, 10, 100, $1000 \mu \mathrm{g} / \mathrm{L}$ ) in two different life stages. Larvae were exposed at 7 and $11^{\circ} \mathrm{C}$ from the eyed ova stage until 8 weeks post yolk sac consumption, and juvenile brown trout were exposed for 4 weeks at $7^{\circ} \mathrm{C}$. At both stages we measured mortality, weight, length, tissue citalopram concentration, behaviour during exposure and behaviour in a stressfull environment. For brown trout larvae additionally hatching rate and heart rate, and for juvenile brown trout the tissue cortisol concentration were assessed.

Results. During the exposure, both larvae and juvenile fish exposed to the highest test concentration of citalopram ( $1 \mathrm{mg} / \mathrm{L}$ ) had higher swimming activity and spent longer in the upper part of the aquaria compared to control fish, which is an indicator for decreased anxiety. Most probably due to the higher swimming activity during the exposure, the juveniles and larvae exposed to $1 \mathrm{mg} / \mathrm{L}$ citalopram showed decreased weight and length. Additionally, in a stressful artificial swimming measurement device, brown trout larvae displayed the anxiolytic effect of the antidepressant by reduced swimming activity during this stress situation, already at concentrations of $100 \mu \mathrm{g} / \mathrm{L}$ citalopram. Chemical analysis of the tissue revealed rising citalopram tissue concentrations with rising exposure concentrations. Tissue concentrations were 10 times higher in juvenile fish compared to brown trout larvae. Fish plasma concentrations were calculated, which exceeded human therapeutic levels for the highest exposure concentration, matching the behavioural results. Developmental parameters like hatching rate and heart rate, as well as mortality and tissue cortisol content were unaffected by the antidepressant. Overall, we could trace the pharmacological mode of action of the antidepressant citalopram in the non-target organism brown trout in two different life stages. 
1 Impact of the antidepressant citalopram on the behaviour 2 of two different life stages of brown trout

3

4 Michael Ziegler ${ }^{1}$, Sarah Knoll², Heinz-R. Köhler ${ }^{1}$, Selina Tisler ${ }^{3}$, Carolin Huhn², Christian

5 Zwiener $^{3}$, Rita Triebskorn ${ }^{1,4}$

6

7 19nimal Physiological Ecology, Eberhard-Karls-Universität Tübingen, Tübingen, Baden-

8 Württemberg, Germany

9 2Effect-based Environmental Analysis, Eberhard-Karls-Universität Tübingen, Baden-

10 Württemberg, Tübingen, Germany

$11{ }^{3}$ Environmental Analytical Chemistry, Eberhard-Karls-Universität Tübingen, Baden-

12 Württemberg, Tübingen, Germany

13 4Steinbeis Transfer Center for Ecotoxicology and Ecophysiology, Rottenburg, Baden-

14 Württemberg, Germany

15

16

17

18

19

20

21

Corresponding Author

Michael Ziegler

Auf der Morgenstelle 5, 72076 Tübingen, Germany

Email adress: michael.ziegler@student.uni-tuebingen.de 


\section{Abstract}

24

25

26

27

28

29

30

31

32

33

34

35

36

37

38

39

40

41

42

43

44

45

46

47

48

49

50

51

52

53

54

55

56

57

58

59

60

61

62

63

64

65

66

Background. Over the last two decades, there has been a constant increase in prescription rates of antidepressants. In parallel, neuroactive pharmaceuticals are making their way into aquatic environments at increasing concentrations. Among the antidepressants detected in the environment citalopram, a selective serotonin reuptake inhibitor, is one of the most commonly found. Given citalopram is specifically designed to alter mood and behaviour in humans, there is growing concern it can adversely affect the behaviour on non-target wildlife

Methods. In our study, brown trout were exposed to citalopram (nominal concentrations: 1, 10, $100,1000 \mu \mathrm{g} / \mathrm{L})$ in two different life stages. Larvae were exposed at 7 and $11^{\circ} \mathrm{C}$ from the eyed ova stage until 8 weeks post yolk sac consumption, and juvenile brown trout were exposed for 4 weeks at $7^{\circ} \mathrm{C}$. At both stages we measured mortality, weight, length, tissue citalopram concentration, behaviour during exposure and behaviour in a stressfull environment. For brown trout larvae additionally hatching rate and heart rate, and for juvenile brown trout the tissue cortisol concentration were assessed.

Results. During the exposure, both larvae and juvenile fish exposed to the highest test concentration of citalopram $(1 \mathrm{mg} / \mathrm{L})$ had higher swimming activity and spent longer in the upper part of the aquaria compared to control fish, which is an indicator for decreased anxiety. Most probably due to the higher swimming activity during the exposure, the juveniles and larvae exposed to $1 \mathrm{mg} / \mathrm{L}$ citalopram showed decreased weight and length. Additionally, in a stressful artificial swimming measurement device, brown trout larvae displayed the anxiolytic effect of the antidepressant by reduced swimming activity during this stress situation, already at concentrations of $100 \mu \mathrm{g} / \mathrm{L}$ citalopram. Chemical analysis of the tissue revealed rising citalopram tissue concentrations with rising exposure concentrations. Tissue concentrations were 10 times higher in juvenile fish compared to brown trout larvae. Fish plasma concentrations were calculated, which exceeded human therapeutic levels for the highest exposure concentration, matching the behavioural results. Developmental parameters like hatching rate and heart rate, as well as mortality and tissue cortisol content were unaffected by the antidepressant. Overall, we could trace the pharmacological mode of action of the antidepressant citalopram in the non-target organism brown trout in two different life stages.

\section{Introduction}

Pharmaceuticals like psychotropic drugs are widely distributed in the environment and can be found in most human-influenced surface waters and within most trophic levels, from algae to fish (Alvarez-Munoz et al. 2015; aus der Beek et al. 2016). During the last decades, psychotropic drugs, especially antidepressants, increasingly detected in rivers and surface waters (Acuna et al. 2015; Grabicova et al. 2017; Hughes et al. 2013; Schultz et al. 2010) due to the increasing numbers of diagnosed mental disorders (Destatis 2017) and the consequent rising numbers of antidepressant prescriptions (Schwabe \& Paffrath 2016). Within the group of antidepressant drugs, the selective serotonin reuptake inhibitors (SSRIs) make up the largest part of the prescription rates (Schwabe \& Paffrath 2016). Their mode of action is based on their binding to the serotonin transporter (SERT) in the presynaptic membrane, thereby inhibiting the reuptake of serotonin into the presynaptic neuron causing increased serotonin levels in the synaptic cleft (Hyttel 1994). These 5-HT reuptake transporters are highly conserved in the animal kingdom and can be found in all phyla (Gunnarsson et al. 2008; Verbruggen et al. 2018). One of the most important antidepressants of the SSRI class is citalopram, which is the most prescribed 
67

antidepressant in Germany, with 306.8 million defined daily doses (DDD) in 2015 (Schwabe \& Paffrath 2016). Assuming a DDD of $20 \mathrm{mg}$ per patient, this leads to a minimum consumption of $6.1 \mathrm{t} / \mathrm{year}$ in Germany alone.

Citalopram has been found in U.S. surface waters in concentrations ranging from $4 \mathrm{ng} / \mathrm{L}$ to 219 $\mathrm{ng} / \mathrm{L}$ (Schultz et al. 2010). In different effluents of wastewater treatment plants, citalopram was found in concentrations ranging from $44 \mathrm{ng} / \mathrm{L}$ to $431 \mathrm{ng} / \mathrm{L}$ (Himmelsbach et al. 2006; Nodler et al. 2010; Silva et al. 2014). Furthermore, surface water citalopram was detected at concentrations of up to $76 \mu \mathrm{g} / \mathrm{L}$ downstream of a wastewater treatment plant in India, close to Hyderabad and up to $840 \mu \mathrm{g} / \mathrm{L}$ in the effluent of a drug manufacturer (Fick et al. 2009; Larsson et al. 2007). In contrast environmental concentrations of other antidepressants like fluoxetine are lower within a range of 1 to $43 \mathrm{ng} / \mathrm{L}$ (Acuna et al. 2015; Paiga et al. 2016; Schultz et al. 2010). With regard to the critical effect concentrations (CEC) published by Fick et al. (2010), it can be seen that citalopram has a very low CEC of $141 \mathrm{ng} / \mathrm{L}$ compared to other antidepressants like fluoxetine (CEC: $489 \mathrm{ng} / \mathrm{L}$ ) or venlafaxine (CEC: $6112 \mathrm{ng} / \mathrm{L}$ ). Despite the fact that citalopram is one of the most commonly prescribed antidepressants and is frequently detected in surface waters, most studies on the effects of SSRIs in fish were performed with other pharmaceuticals like fluoxetine (Airhart et al. 2007; Foran et al. 2004; Henry \& Black 2008; Martin et al. 2017); as a result, there is a deficit in knowledge concerning the effects of citalopram in fish. At present, the impact of citalopram on fish have been mixed: Kellner et al. (2016) showed reduction in anxiety related behaviour indicated by an increase in the swimming activity in three-spined sticklebacks and a longer time spent in the upper part of the aquaria, caused by exposure to $1.5 \mu \mathrm{g} / \mathrm{L}$ citalopram for 21 days. In addition, anxiolytic effects like reduced freezing behaviour in the novel tank diving test and increased curiosity in the novel object test were observed after exposure to 15 and 1.5 $\mu \mathrm{g} / \mathrm{L}$ of citalopram respectively for 21 days. Whereas, Kellner et al. (2017) exposed three-spined sticklebacks in a developmental stage for 30 days to $1.5 \mu \mathrm{g} / \mathrm{L}$ citalopram with a subsequent 120 days recovery phase and showed a reduced swimming activity in the novel tank diving test as well as increased aggressive behaviour. Though, neither freezing behaviour and latency or number of transitions spent in the upper half were influenced, which can be seen as no change in anxiety. But, Olsen et al. (2014) could show anxiolytic effects in the novel tank diving test, like reduced freezing behaviour and faster and longer time spent in the upper aquaria in Endler's guppies exposed to 2.3 and $15 \mu \mathrm{g} / \mathrm{L}$ of citalopram for 21 days. With regard to feeding behaviour, Kellner et al. (2015) showed that three-spined sticklebacks had reduced food intake when exposed to $0.15 \mu \mathrm{g} / \mathrm{L}$ citalopram for 21 days. But in contrast, Kellner et al. (2017) observed increased food intake in sticklebacks exposed to $1.5 \mu \mathrm{g} / \mathrm{L}$ citalopram for 30 days during developmental stages, and a subsequent 120 days recovery phase. Keysomi et al. (2013) also proved a decrease in plasma cortisol level in rainbow trout (Oncorhynchus mykiss) exposed to 5 $\mu \mathrm{g} / \mathrm{L}$ citalopram for 10 days. Due to these diverse outcomes, it is important to assess different endpoints in different life stages to detect the diverse effects that citalopram can have on aquatic organisms. In our case, two life stages of the native fish species brown trout (Salmo trutta f. fario) were chosen because of the species' sensitivity and high ecological relevance in central Europe (Klemetsen et al. 2003). To assess the effects of citalopram on developmental parameters like mortality, time to hatch and heart rate, we exposed brown trout eggs to citalopram at 7 and $11^{\circ} \mathrm{C}$ for 5 months until 8 weeks post yolk consumption. Also, juvenile brown trout were 
110

111

112

113

114

115

116

117

118

119

120

121

122

123

124

125

126

127

128

129

130

131

132

133

134

135

136

137

138

139

140

141

142

143

144

145

146

147

148

149

150

exposed to citalopram for 4 weeks at $7^{\circ} \mathrm{C}$, and the apical endpoints mortality, weight and length were evaluated. The cortisol content of the juvenile fish was assessed. Cortisol is a glucocorticoid hormone which has various effects in fish like the regulation of hydro-mineral balance and energy metabolism (Wendelaar Bonga 1997), and it can be used as an indicator of stress. In addition, in both experiments behavioural parameters were recorded during the exposure period. The preference of the fish to stay in the upper aquaria part in the exposure tanks was assessed and swimming behaviour in a stressful environment was recorded using an artificial swimming measurement device. The aim of this study was to evaluate effects of citalopram on developmental and behavioural endpoints. Furthermore, the study aimed at showing whether these effects occur under chronic exposure at environmentally relevant concentrations.

\section{Material and methods}

\section{Fish}

Brown trout (Salmo trutta f. fario) eggs and juveniles were purchased from a trout farm in Southern Germany (Forellenzucht Lohmühle, Alpirsbach-Ehlenbogen, Germany). This commercial fish breeder is listed as category I (disease-free) according to the EC Council Directive (2006). The eggs were obtained in the eyed ova stage in December 2016 and directly transferred into the experiment. The juveniles were acclimatised to laboratory conditions for two weeks prior to exposure in a $200 \mathrm{~L}$ tank (filtered tap water, aerated) and exposed afterwards in August 2017. Fish were kept under a 10:14 light:dark regime and fed daily with commercial trout feed (0.8 mm, Inico Plus, Biomar, Brande, Denmark). All animals were approved by the animal welfare committee of the Regional Council of Tübingen, Germany (ZO 2/16).

\section{Test Substance}

Citalopram hydrobromide $\left(\mathrm{C}_{20} \mathrm{H}_{21} \mathrm{FN}_{2} \mathrm{O} \cdot \mathrm{HBr}\right.$, CAS: 59729-32-7) was purchased from Sigma Aldrich (Steinheim, Germany). It was dissolved in distilled water to obtain stock solutions of 100 $\mathrm{mg} / \mathrm{L}$ and $1 \mathrm{mg} / \mathrm{L}$ citalopram. The citalopram concentrations refer to citalopram free base $\left(\mathrm{C}_{20} \mathrm{H}_{21} \mathrm{FN}_{2} \mathrm{O}\right)$. To achieve the respective nominal concentrations, test solutions were prepared with appropriate volumes of the equivalent stock solutions and aerated, filtered tap water (iron filter, active charcoal filter, particle filter).

\section{Experiment with brown trout larvae}

Brown trout eggs in the eyed ova stage (37 days post fertilisation (dpf)) were exposed in a semi static setup with three replicate each of $0,1,10,100,1000 \mu \mathrm{g} / \mathrm{L}$ citalopram at both $7^{\circ} \mathrm{C}$ or $11^{\circ} \mathrm{C}$, in order to reveal influences of temperature on the effects investigated. Additionally, we had one tank in each of the three replicate blocks with $100 \mu \mathrm{g} / \mathrm{L}$ citalopram but without fish, which served as a control for ingestion, photolytic and microbial degradation of the chemical. Aquaria containing $10 \mathrm{~L}$ test solution and 30 fish each were set up in triplicate in a randomised order. Twice a week, $50 \%$ of the test solution were replaced with freshly prepared test solution. A 10:14 light:dark cycle was set and the tanks were covered with black foil to protect them from direct light. Fish were fed daily $(0.5 \mathrm{~mm}, 0.8 \mathrm{~mm}$, Inico Plus, Biomar, Brande, Denmark) from the day the yolk-sac was consumed (for $7^{\circ} \mathrm{C}: 52 \mathrm{~d}$ post hatch; for $11^{\circ} \mathrm{C}: 35 \mathrm{~d}$ post hatch) with a defined amount of food ( $3 \%$ body weight) adjusted to the developmental state of the fish. 
151 Exposure ended 8 weeks (total exposure time $7^{\circ} \mathrm{C}$ : $135 \mathrm{~d} ; 11^{\circ} \mathrm{C}$ : $107 \mathrm{~d}$ ) after yolk-sac

152

153

154

155

156

157

158

159

160

161

162

163

164

165

166

167

168

169

170

171

172

173

174

175

176

177

178

179

180

181

182

183

184

185

186

187

188

189

190

191

consumption. During the exposure, time to hatch and mortality were recorded daily. At 7 days post-hatch, the heart rate of 5 individuals of each control and the highest concentration tank was measured and, whenever a difference was revealed, the other treatments were also assessed. Two weeks before sampling, pictures of the photographable tanks were taken on a daily basis to assess the number of fish in the upper and lower aquaria part during exposure. One week before the last sampling, the swimming behaviour was recorded using an artificial swimming measurement device (ASMD). Here, 5 fish from each tank were transferred into small glass aquaria and swimming behaviour was recorded for 18 minutes. Terminally, fish were sampled 8 weeks after yolk sac consumption. When sampling took place, the fish were anaesthetised by an overdose of the fish anaesthetic MS222 (tricaine mesylate, $1 \mathrm{~g} / \mathrm{L}$, buffered with $\mathrm{NaHCO}_{3}$ ) followed by a cervical spine cut. After individual determination of the weight and the total length fish were dissected, and tailfins were frozen in liquid nitrogen and stored at $-80^{\circ} \mathrm{C}$ for further analysis of citalopram tissue content. Water conditions (temperature, conductivity, $\mathrm{pH}$, oxygen content) were tested at the beginning, twice during the experiment and at the end.

\section{Experiment with juvenile brown trout}

Juvenile brown trout ( 8 months post hatch) were exposed at $7^{\circ} \mathrm{C}$ in a semi-static three block setup to $0,1,10,100,1000 \mu \mathrm{g} / \mathrm{L}$ citalopram for 28 days. The treatments were setup in triplicate in a randomised order in aquaria containing $15 \mathrm{~L}$ of the test solution and 10 fish each. Twice a week, $50 \%$ of the test solution were renewed. The test was conducted under a 10:14 light:dark regime at $7^{\circ} \mathrm{C}$, and the tanks were covered with black foil to protect them from direct light. Fish were fed daily with a defined amount ( $3 \%$ body weight) of commercial trout feed $(0.8 \mathrm{~mm}$, Inico Plus, Biomar, Brande, Denmark). Mortality was recorded daily. From two weeks before the sampling took place until the end of the experiment, daily pictures of the photographable tanks were taken to assess the number of fish in the upper and lower aquaria portion during the exposure. In addition, three fish from each tank were used for swimming behaviour measurements in the artificial swimming measurement device (ASMD) explained further below and sampled afterwards. At the end of the experiment, 7 of the 10 fish per tank were anaesthetised and killed by an overdose of the fish anaesthetic, MS222 (Tricaine mesylate, $1 \mathrm{~g} / \mathrm{L}$, buffered with $\mathrm{NaHCO}_{3}$ ) followed by a cervical spine cut. Prior to dissection, the weight and total length of fish were determined. The dorsal part and tailfin of the fish were frozen in liquid nitrogen and stored at $-80^{\circ} \mathrm{C}$ for further analysis of cortisol and citalopram tissue content. Water conditions were tested at the beginning and end of the experiment, and water samples for chemical analyses were taken right before the start of the experiment, after 2 weeks and at the end of the experiment.

\section{Chemical analyses}

Water samples were taken at the beginning, in the course and at the end of the experiments. Sampling during the exposure period took place regularly before and after water exchange. Water samples from triplicate aquaria were pooled and stored at $-20^{\circ} \mathrm{C}$ until further processing. For tissue analysis, at the end of the experiments, tailfin samples of the fish were taken to determine the citalopram concentration in the muscle. 


\section{Water analysis}

193 The real water concentrations were determined using LC-MS with a 1290 Infinity HPLC system

194 (Agilent Technologies, Waldbronn, Germany) and a triple quadrupole mass spectrometer (6490

195 iFunnel Triple Quadrupole LC/MS, Agilent Technologies, Santa Clara, CA, USA) in ESI (+)

196 mode. An Agilent Poroshell-120-EC-C18 column $(2.1 \times 100 \mathrm{~mm} ; 2.7 \mu \mathrm{m}$ particle size $)$ was used 197 at a flow rate of $0.4 \mathrm{~mL} / \mathrm{min}$ for separation, and column temperature was maintained at $40^{\circ} \mathrm{C}$.

198 Eluent A and B were water ( $+0.1 \%$ formic acid) and acetonitrile $(+0.1 \%$ formic acid),

199 respectively. Gradient elution was used: $0-1 \mathrm{~min} 5 \% \mathrm{~B}$, linear increase to $100 \%$ B within 7 min, 200 hold for $7 \mathrm{~min}$ at $100 \% \mathrm{~B}$. After switching back to the starting conditions, a reconditioning time 201 of 3 min was employed. Samples were kept in the autosampler at $10^{\circ} \mathrm{C}$. The injection volume 202 was 1 or $10 \mu \mathrm{l}$ (dilution factor $0-100$ ). The limit of detection of citalopram (mass transition $\mathrm{m} / \mathrm{z}$ $203325 \rightarrow 109)$ for undiluted samples was $10 \mathrm{ng} / \mathrm{L}(10 \mu \mathrm{L}$ injection volume). Further details on the 204

205

206

207

208

209

210

211

212

213

214

215

216

217

218

219

220

221

222

223

224

225

226

227

228

229

230

231

232 operating parameters of the triple quadrupole are provided in the supplement.

\section{Tissue analysis}

The citalopram concentrations in the tissues of brown trout larvae and juveniles were determined by liquid chromatography-mass spectrometry (LC-MS). For sample extraction, a miniaturised and optimised QuEChERS procedure was applied. Fish samples (tailfin samples containing mainly muscle tissue) originating from all exposure concentrations were analysed. For each exposure group, tissue samples of 10 individuals per treatment were pooled. Frozen fish samples $\left(-20^{\circ} \mathrm{C}\right)$ were first homogenised by grinding using a mortar and pestle under liquid nitrogen. Aliquots of the homogenised samples were transferred to an Eppendorf tube, and $0.25 \mathrm{~mL}$ acetonitrile and $0.75 \mathrm{~mL}$ water were added. For extraction, samples were shaken with a vortex device for $30 \mathrm{sec}$, after which $30 \mathrm{mg}$ sodium chloride and $120 \mathrm{mg}$ anhydrous magnesium sulfate were added; and the sample was immediately shaken for $30 \mathrm{sec}$. After centrifugation for $15 \mathrm{~min}$ at $13000 \mathrm{rpm}, 0.1 \mathrm{~mL}$ of the acetonitrile phase were evaporated to dryness under a gentle stream of nitrogen and the concentrated residue was resolved in $0.3 \mathrm{~mL}$ methanol. The extracts were diluted to reach concentrations compatible with the calibration range established for citalopram, and filtered for LC-MS analysis. Matrix matched calibration was performed between 1 and 20 $\mu \mathrm{g} / \mathrm{L}$. The limit of detection was $0.06 \mathrm{ng} / \mathrm{g}$. Further details can be found in the supplementary material.

All analyses were performed using a 1260 Infinity LC system coupled to a 6550 iFunnel QTOF mass spectrometer (Agilent Technologies, Waldbronn, Germany and Santa Clara, CA, USA) with an electrospray ionisation source (ESI). Aliquots of $10 \mu \mathrm{L}$ sample were injected onto a Zorbax Eclipse Plus C18 column (2.1 x 150 mm; $3.5 \mu \mathrm{m}$ particle size, narrow bore, Agilent Technologies, Waldbronn, Germany) at a column temperature of $40^{\circ} \mathrm{C}$. A gradient elution at a flow rate of $0.3 \mathrm{~mL} / \mathrm{min}$ using water and methanol, containing $0.1 \%$ formic acid, was used. Details on the LC-MS method are given in the supplementary material.

\section{Swimming behaviour in exposure aquaria}

For quantification of the swimming behaviour during the exposure, photos of tanks were taken and the number of fish in the upper and lower aquaria part was counted. This was only possible for some aquaria ( 8 of 15 for brown trout larvae, 9 of 15 for juvenile brown trout) due to their 
233 position in the climate chamber. Nevertheless, the selection of photographable tanks was

234 representative for the entire number of aquaria, because for control and the highest treatment at

235 least 2 tanks were photographed. Pictures were taken with a Panasonic DMC-TZ56 camera 5

236 minutes after the black foil cover was removed; a white sheet of paper was placed in the back of

237 the aquarium to provide a bright background for better contrast. For experiments with brown

238 trout larvae, 3 pictures were taken per day of each photographable tank at an interval of 5

239 minutes, from one-week prior to the experiment until sampling (Apr 03 - Apr 13, 2017). In the

240 juvenile brown trout experiment, 3 pictures were taken every day of each photographable tank at

241 an interval of 5 minutes, from two weeks before sampling until sampling (Aug 21 - Sep 03,

242 2017). The pictures were analysed manually and the number of fish located in the lower and

243 upper half of the aquaria was recorded. Data for all pictures taken from one tank on the same day

244 were averaged.

245

246

247

248

249

250

251

252

253

254

255

256

257

258

259

260

261

262

263

264

265

266

267

268

269

270

271

272

273

274

\section{Artificial swimming measurement device (ASMD)}

The recording of the brown trout larvae took place one week before the second sampling of the fish. Small aquaria $(17 \times 17 \times 8.5 \mathrm{~cm})$ were filled with $500 \mathrm{ml}$ of the respective test solution at an appropriate temperature, and five brown trout larvae were placed in there. The testing of juvenile fish was scheduled after the sampling, where the swimming behaviour of the three leftover juvenile brown trout from each tank was recorded. One litre of the respective test solution was added to the small aquaria, before the three juvenile fish were transferred to them and recorded. Each of the four small aquaria was equipped with a camera (Basler acA 1300-60 gm, 1.3 MP resolution, Basler AG, Ahrensburg, Germany, lens: 4.5-12.5 mm; 1:1.2; IR 1/2") placed $32 \mathrm{~cm}$ above the water surface. The set-up was arranged on a table in the climate chamber and enclosed by white polystyrene plates on each side and on top. Inside the enclosure, 4 lamps $(2700 \mathrm{~K}, 1521$ $\mathrm{lm}$ each) were placed, one in each corner facing the top polystyrene plate to obtain indirect illumination. The bright illumination, lack of aeration of the ASMD-aquaria and the transfer process of the fish led to stressful conditions for them. Locomotion was recorded for 20 minutes, but the first 2 minutes were ignored to account for acclimatisation. During the remaining $18 \mathrm{~min}$, video sequences were taken and each of the four aquaria was analysed individually. Fish were centre-point tracked individually, and the total distance moved, the average velocity and the time of no movement were logged with the EthoVision 12 XT (Noldus Information Technology bv, Wageningen, Netherlands). A manual correction of some of the tracked data was essential due to difficulties in automatic tracking.

\section{Cortisol content}

Cortisol content was determined in juvenile brown trout exposed under stressful conditions in the ASMD as well as in fish not exposed to such stress. The cortisol content was measured with the commercially available Fish cortisol ELISA Kit by Cusabio Technology LCC (Houston, Texas, USA). The dorsal parts (muscle and kidney tissue) of juvenile brown trout were manually homogenised in 1xPBS buffer (tissue/buffer ratio $1: 11 \mathrm{w} / \mathrm{v}$ ) with a pestle. After 2 freeze-thaw cycles at $-20^{\circ} \mathrm{C}$ and room temperature, the samples were centrifuged $\left(5000 \mathrm{x} \mathrm{g}, 5 \mathrm{~min}, 4^{\circ} \mathrm{C}\right)$ and the supernatant stored at $-20^{\circ} \mathrm{C}$ until analysis. Before pipetting the assay, the supernatant was diluted with sample buffer provided in the Kit (supernatant/buffer ratio $1: 10 \mathrm{v} / \mathrm{v}$ ). The assay was conducted in a pre-coated 96 well plate provided by the manufacturer. Each well contained 50 
275

276

277

278

279

280

281

282

283

284

285

286

287

288

289

290

291

292

293

294

295

296

297

298

299

300

301

302

303

304

305

306

307

308

309

310

311

312

313

$\mu \mathrm{L}$ antibody and either $50 \mu \mathrm{L}$ of standard or $50 \mu \mathrm{L}$ of sample, before being incubated for 40 min at $37^{\circ} \mathrm{C}$. After 3 washing cycles with washing buffer, $100 \mu \mathrm{L}$ of HRP-conjugate was added and incubated for $30 \mathrm{~min}$ at $37^{\circ} \mathrm{C}$. Following 5 washing cycles with washing buffer, $90 \mu \mathrm{L}$ of TMB (3,3',5,5'-Tetramethyl[1,1'-biphenyl]-4,4'-diamine) substrate were added and incubated for 20 minutes at $37^{\circ} \mathrm{C}$. Then, $50 \mu \mathrm{L}$ of stop solution were added to each well and the plate was measured photometrically at $450 \mathrm{~nm}$ and for wavelength correction at $570 \mathrm{~nm}$. Concentrations were calculated with blanked and wavelength corrected data to a four parameter logistic standard curve fit. Concentrations of cortisol are expressed in $\mathrm{ng} / \mathrm{mL}$ (see Table 1).

\section{Statistical analysis}

Statistical analyses were performed with SAS JMP 14 and R 3.5.0 (packages: lme4). Mortality and time to hatch were analysed by nested Cox proportional hazards model, using replicate aquaria as a nested factor. Length, weight and total distance moved of the ASMD were analysed by a nested ANOVA, using replicate aquaria as nested factor, and a post hoc Dunnett's test. If necessary, data were transformed to achieve normal distribution and homogeneity of variance. If no normal distribution could be achieved, data were evaluated with a nonparametric KruskalWallis test post-hoc Steel method with control. The difference in cortisol content, mean velocity and no movement ofer time of the ASMD was analysed with a Linear Mixed Model with replicate as random factor and subsequently post-hoc Dunnett's test. Data for swimming behaviour during the exposure were evaluated with a Generalized Linear Mixed Model (binomial distribution, aquarium identity as random factor) and supsequently post-hoc Dunnett's Test. The $\alpha$-level was set to 0.05 . Comparison of the results for different climate chambers was only descriptive to prevent the problem of pseudo-replication due to missing climate chamber replicates. Statistical details are given in the supplementary material.

\section{Criteria for reporting and evaluating ecotoxicity data (CRED)}

Criteria for reporting and evaluating ecotoxicity data (CRED) are given in the supplementary material (Moermond et al. 2016). CRED is important to improve the reproducibility, relevance and transparency of aquatic ecotoxic research between the different institutions (Moermond et al. 2016).

\section{Results}

\section{Water conditions}

Temperature, conductivity, $\mathrm{pH}$ and oxygen content were measured at the beginning and end of both experiments. In the brown trout larvae experiment, water quality parameters were assessed at 2 additional time points $(18.01 .2017,06.03 .2017)$. All water quality parameters were in an acceptable range (brown trout larvae: mean temperature $7^{\circ} \mathrm{C}: 7.1 \pm 0.32^{\circ} \mathrm{C} ; 11^{\circ} \mathrm{C}: 10.47 \pm$ $0,24^{\circ} \mathrm{C}$; mean conductivity $7^{\circ} \mathrm{C}: 472.6 \pm 9.9 \mu \mathrm{S} / \mathrm{cm} ; 11^{\circ} \mathrm{C}: 478.3 \pm 7.2 \mu \mathrm{S} / \mathrm{cm}$; mean $\mathrm{pH} 7^{\circ} \mathrm{C}$ : $8.08 \pm 0.41 ; 11^{\circ} \mathrm{C}: 7.96 \pm 0.46$; mean oxygen content $7^{\circ} \mathrm{C}: 10.77 \pm 0.3 \mathrm{mg} / \mathrm{L} ; 11^{\circ} \mathrm{C}: 9.94 \pm 0.5$ $\mathrm{mg} / \mathrm{L}$; juvenile brown trout: mean temperature: $7.15 \pm 0.41^{\circ} \mathrm{C}$; mean conductivity: $493.7 \pm 17.5$ $\mu \mathrm{S} / \mathrm{cm}$; mean $\mathrm{pH}: 8.09 \pm 0.01$; mean oxygen content: $11.22 \pm 0.1 \mathrm{mg} / \mathrm{L})$. Further details are given in the supplementary materials. 
314

315

316

317

318

319

320

321

322

323

324

325

326

327

328

329

330

331

332

333

334

335

336

337

338

339

340

341

342

343

344

345

346

347

348

349

350

351

352

353

354

\section{Chemical analyses}

Regarding water analysis, citalopram could not be detected in any of the control samples. In most of the treatments, aqueous citalopram concentrations measured were lower than nominal concentrations, except for the treatments with the highest concentrations in the brown trout larvae experiment and the exposure at $1 \mu \mathrm{g} / \mathrm{L}$ of the juvenile brown trout experiment. The recovery rate was about $80 \%$. The citalopram concentrations in the controls for photolytic and microbial degradation were slightly higher $(79.84 \pm 2.50 \mu \mathrm{g} / \mathrm{L})$ than in the $100 \mu \mathrm{g} / \mathrm{L}$ exposure $\operatorname{tank}(70.50 \pm 11.11 \mu \mathrm{g} / \mathrm{L})$. Overall, the measured citalopram concentrations in water samples were in good accordance with the nominal concentrations (Table 1). Further details on water concentrations are given in the supplementary materials.

Regarding biota analysis, citalopram determined in tissue samples was in the $\mu \mathrm{g} / \mathrm{g}$ range. Citalopram could not be detected in the muscle tissue of brown trout in any of the control samples. Tissue concentrations of citalopram were shown to correlate with water concentrations with the highest values in fish exposed to $1000 \mu \mathrm{g} / \mathrm{L}$ citalopram. Tissue concentrations of brown trout larvae exposed at $7^{\circ} \mathrm{C}$ were higher than those of brown trout larvae exposed at $11^{\circ} \mathrm{C}$. Juvenile brown trout accumulated at least 20 times more citalopram in muscle tissue than brown trout larvae.

\section{Experiment with brown trout larvae}

Table

The mortality of brown trout larvae was not affected by citalopram $\left(11^{\circ} \mathrm{C}\right.$ Cox Regression: $\mathrm{df}=4$, $\chi 2=4.2743, \mathrm{p}=0.370 ; 7^{\circ} \mathrm{C}$ Cox Regression: $\left.\mathrm{df}=4, \chi 2=6.9203, \mathrm{p}=0.140\right)$. However, the mortality of larvae exposed at $11^{\circ} \mathrm{C}$ was higher in all treatments, including the controls, from day 51 to day 86 of exposure ( $43 \mathrm{~d}-71 \mathrm{~d}$ post hatch) $\left(11^{\circ} \mathrm{C}\right.$ mean mortality $\left.29.11 \%\right)$. The mortality of fish exposed to $7^{\circ} \mathrm{C}$ ranged from $0-10 \%\left(7^{\circ} \mathrm{C}\right.$ mean mortality $\left.4.69 \%\right)$. Also, time to hatch did not differ between treatments $\left(11^{\circ} \mathrm{C}\right.$ : Cox Regression: $\mathrm{df}=4, \chi 2=0, \mathrm{p}=1 ; 7^{\circ} \mathrm{C}$ : Cox Regression: $\mathrm{df}=4$, $\chi 2=2.42 \mathrm{E}-0.9, \mathrm{p}=1)$. The fish exposed at $11^{\circ} \mathrm{C}$ hatched approximately 10 days earlier than fish exposed at $7^{\circ} \mathrm{C}$. The heart rate of brown trout larvae was not affected when exposed to 1000 $\mu \mathrm{g} / \mathrm{L}$ citalopram at $11^{\circ} \mathrm{C}$ (nested ANOVA: $\mathrm{df}=1, \mathrm{~F}=0.3968, \mathrm{p}=0.535$ ) and $7^{\circ} \mathrm{C}$ (nested ANOVA: $\mathrm{df}=4, \mathrm{~F}=2.6161, \mathrm{p}=0.045$; post-hoc Dunnett's test no difference to control). The heart rate of the fish exposed at $11^{\circ} \mathrm{C}$ was about 20 beats per minute higher on the average than in fish exposed at $7^{\circ} \mathrm{C}$. The weight and length of fish exposed to $1000 \mu \mathrm{g} / \mathrm{L}$ citalopram was significantly lower compared to the control at both temperatures (Table 1$)\left(11^{\circ} \mathrm{C}\right.$ weight: nested ANOVA: $\mathrm{df}=4$, $\mathrm{F}=12.8137, \mathrm{p}<0.001$; post-hoc Dunnett's test $[0 \mu \mathrm{g} / \mathrm{L} \mid 1000 \mu \mathrm{g} / \mathrm{L}] \mathrm{p}<0.001 ; 11^{\circ} \mathrm{C}$ length: nested ANOVA: $\mathrm{df}=4, \mathrm{~F}=13.1786, \mathrm{p}<0.001$; post-hoc Dunnett's test $[0 \mu \mathrm{g} / \mathrm{L} \mid 1000 \mu \mathrm{g} / \mathrm{L}] \mathrm{p}<0.001 ; 7^{\circ} \mathrm{C}$ weight: nested ANOVA: df $=4, \mathrm{~F}=9.7415, \mathrm{p}<0.001$; post-hoc Dunnett's test $[0 \mu \mathrm{g} / \mathrm{L} \mid 1000 \mu \mathrm{g} / \mathrm{L}]$ $\mathrm{p}<0.001 ; 7^{\circ} \mathrm{C}$ length: nested ANOVA: $\mathrm{df}=4, \mathrm{~F}=22.0216, \mathrm{p}<0.001$; post-hoc Dunnett's test $[0 \mu \mathrm{g} / \mathrm{L} \mid 1000 \mu \mathrm{g} / \mathrm{L}] \mathrm{p}<0.001)$.

\section{Swimming behaviour during exposure}

We could show that citalopram had an effect on the stay of the fish in the upper half of the aquaria at both temperatures. Significantly more fish exposed to $1000 \mu \mathrm{g} / \mathrm{L}$ citalopram stayed close to the water surface compared to the control fish at both temperatures. Fish exposed to 1 
and $10 \mu \mathrm{g} / \mathrm{L}$ citalopram concentrations at $7^{\circ} \mathrm{C}$ stayed slightly more often in the upper half of the aquaria than control fish (Table 1) $\left(11^{\circ} \mathrm{C}\right.$ : Generalized Linear Mixed Model, $\mathrm{df}=4, \mathrm{~F}=12.4141$, post-hoc Dunnett's $[0 \mu \mathrm{g} / \mathrm{L} \mid 1000 \mu \mathrm{g} / \mathrm{L}] \mathrm{p}<0.001 ; 7^{\circ} \mathrm{C}$ : Generalized Linear Mixed Model, df $=4$, $\mathrm{F}=106.9664$, post-hoc Dunnett's $[0 \mu \mathrm{g} / \mathrm{L} \mid 1 \mu \mathrm{g} / \mathrm{L}] \mathrm{p}=0,027,[0 \mu \mathrm{g} / \mathrm{L} \mid 10 \mu \mathrm{g} / \mathrm{L}] \mathrm{p}=0.017,[0$ $\mu \mathrm{g} / \mathrm{L} \mid 1000 \mu \mathrm{g} / \mathrm{L}] \mathrm{p}<0.001)$.

ASMD

Figure 1

Overall, fish exposed at $11^{\circ} \mathrm{C}$ swam further and faster in the ASMD than fish exposed at $7^{\circ} \mathrm{C}$. Furthermore, the citalopram treatments also revealed an effect on the total distance moved and the mean velocity during the recordings in the ASMD. Fish exposed to $1000 \mu \mathrm{g} / \mathrm{L}$ citalopram at $11^{\circ} \mathrm{C}$ swam significantly less and slower than control fish (distance moved: nested ANOVA: $\mathrm{df}=4, \mathrm{~F}=4.7551, \mathrm{p}=0.002$; post-hoc Dunnett's test $[0 \mu \mathrm{g} / \mathrm{L} \mid 1000 \mu \mathrm{g} / \mathrm{L}] \mathrm{p}=0.001)$. Also, fish exposed at $7^{\circ} \mathrm{C}$ showed significantly less total distance moved and had a lower mean velocity when exposed to $100 \mu \mathrm{g} / \mathrm{L}$ or $1000 \mu \mathrm{g} / \mathrm{L}$ citalopram, compared to control fish (Table 1, Figure 1, A, D) (distance moved: nested ANOVA: $\mathrm{df}=4, \mathrm{~F}=7.8214, \mathrm{p}<0.001$; post-hoc Dunnett's test [0 $\mu \mathrm{g} / \mathrm{L} \mid 100 \mu \mathrm{g} / \mathrm{L}] \mathrm{p}=0.021[0 \mu \mathrm{g} / \mathrm{L} \mid 1000 \mu \mathrm{g} / \mathrm{L}] \mathrm{p}<0.001)$. Furthermore, it can be seen that control brown trout larvae have an increased time of no movement at the beginning of the experiment, which decreases overtime. Contrary mean velocity at the beginning of the experiment is lower and increases with time and has its peak at 12 minutes. In contrast brown trout larvae exposed to the highest treatment have a constant lower mean velocity over time and a constant longer time of no movement over recordingtime (Figure 1, B-C, E-F). Brown trout larvae exposed to 100 and $1000 \mu \mathrm{g} / \mathrm{L}$ at $7^{\circ} \mathrm{C}$ show significant decreased mean velocity and increased time of no movement over time (mean velocity: Linear mixed model: $\mathrm{df}=4 ; 10, \mathrm{~F}=5.6897, \mathrm{p}=0.012$, post-hoc Dunnett's $[0 \mu \mathrm{g} / \mathrm{L} \mid 100 \mu \mathrm{g} / \mathrm{L}] \mathrm{p}=0.024,[0 \mu \mathrm{g} / \mathrm{L} \mid 1000 \mu \mathrm{g} / \mathrm{L}] \mathrm{p}<0.001$; no movement: Linear mixed model: $\mathrm{df}=4 ; 10, \mathrm{~F}=5.4797, \mathrm{p}=0.013$, post-hoc Dunnett's $[0 \mu \mathrm{g} / \mathrm{L} \mid 100 \mu \mathrm{g} / \mathrm{L}] \mathrm{p}=0.041,[0 \mu \mathrm{g} / \mathrm{L} \mid 1000 \mu \mathrm{g} / \mathrm{L}]$ $\mathrm{p}<0.001)$. Brown trout larvae exposed at $11^{\circ} \mathrm{C}$ do not show significant difference, though a statistical trend is visible (mean velocity: Linear mixed model: $\mathrm{df}=4 ; 10, \mathrm{~F}=2.7222, \mathrm{p}=0.091$, no movement: Linear mixed model: $d f=4 ; 10, F=3.1072, p=0.066$ ).

\section{Experiment with juvenile brown trout}

Table 2

No mortality occurred during the experiment. Weight and length were significantly lower in fish exposed to $1000 \mu \mathrm{g} / \mathrm{L}$ citalopram compared to control fish (weight: nested ANOVA: $\mathrm{df}=4$, $\mathrm{F}=3.2964, \mathrm{p}=0.001$; post-hoc Dunnett's test $[0 \mu \mathrm{g} / \mathrm{L} \mid 1000 \mu \mathrm{g} / \mathrm{L}] \mathrm{p}=0.023$; length: nested ANOVA: df=4, F=4.6661, $\mathrm{p}=0.002$; post-hoc Dunnett's test $[0 \mu \mathrm{g} / \mathrm{L} \mid 1000 \mu \mathrm{g} / \mathrm{L}] \mathrm{p}=0.019$ ).

\section{Swimming during exposure}

There was a strong effect of the highest citalopram concentration on the swimming behaviour of fish: About $25 \%$ of the $1000 \mu \mathrm{g} / \mathrm{L}$ citalopram-treated fish stayed in the upper half of the aquaria, in contrast to the control and other treatments, where no fish stayed in the upper aquaria part (Generalized linear mixed model, df=4, $F=7.3259$, post-hoc Dunnett's $[0 \mu \mathrm{g} / \mathrm{L} \mid 1000 \mu \mathrm{g} / \mathrm{L}]$ $\mathrm{p}=0,0011)$ (Table 2). 
395

396

397

398

399

400

401

402

403

404

405

406

407

408

409

410

411

412

413

414

415

416

417

418

419

420

421

422

423

424

425

426

427

428

429

430

431

432

433

434

435

ASMD

In the artificial swimming measurement device, neither the total distance moved nor the mean velocity of the exposed fish differed significantly to the control (Table 2, Figure 1, G)(distance moved: nested ANOVA: $\mathrm{df}=4$. $\mathrm{F}=1.0846$. $\mathrm{p}=0.382$; velocity: nested ANOVA: $\mathrm{df}=4, \mathrm{~F}=1.0846$, $\mathrm{p}=0.382$ ). Mean total distance moved and averaged mean velocity of the exposed fish were about $70 \%$ of the fish from the control; however, this was not significant. The behaviour pattern over time does not differ strongly between control and treated fish. At the beginning juvenile brown trout have a reduces mean velocity, which increases over time. Opposed to this time of no movement is decreasing over time (Figure 1, H-I). Statsitical difference between exposed and control fish could not be revealed with regard to mean velocity and no movement over time (mean velocity: Linear mixed model: $\mathrm{df}=4 ; 10, \mathrm{~F}=0.4324, \mathrm{p}=0.782$; no movement: Linear mixed model: $\mathrm{df}=4 ; 10, \mathrm{~F}=0.4902, \mathrm{p}=0.743$ ).

\section{Cortisol}

Figure 2

Tissue cortisol concentrations did not differ between exposed and control fish. The citalopram exposed fish did not show significant differences between the treatments (Table 2, Figure 2) (Linear Mixed Model: $\mathrm{df}=4,68.638, \mathrm{~F}=3.7625, \mathrm{p}=0.008$, post-hoc Dunnett's Test revealed no difference between control and treatments). However, there was a significant increase in tissue cortisol content in fish tested in the ASMD (mean cortisol content: $26.66 \pm 18.57$ ) compared to fish not tested in the ASMD (mean cortisol content: $15.22 \pm 10.16)$ (Linear Mixed Model: $\mathrm{df}=1,95.378, \mathrm{~F}=16.7132, \mathrm{p}<0.001)($ Figure 2).

\section{Discussion}

This study shows that citalopram affects the swimming behaviour and growth of brown trout in different life stages. Effect concentrations were close to citalopram concentrations measured in wastewater effluents (Fick et al. 2009; Larsson et al. 2007; Nodler et al. 2010; Vasskog et al. 2006).

\section{Bioconcentration}

It has been shown that citalopram can accumulate in the liver, kidney and brain of fish (Grabicova et al. 2017; Grabicova et al. 2014). In the present study, we analysed tail fin tissue samples (muscle) since all other organs were used for biomarker analyses. The obtained data made evident that even early life stages of brown trout but, more intensely, juveniles accumulate citalopram in their muscle tissue. In both life stages, citalopram tissue concentrations rose slightly with increasing exposure concentrations of 1 to $100 \mu \mathrm{g} / \mathrm{L}$ (Table 1 and Table 2). When comparing the aqueous with the tissue concentration there is a linear relationship between exposure concentrations and internal concentration (Supplemental material, Figure 1). Citalopram concentrations in fish exposed at $7^{\circ} \mathrm{C}$ (135 days) were about 3 times higher than those in fish exposed at $11^{\circ} \mathrm{C}(107$ days), possibly due to the longer exposure time of about 4 weeks. The muscle tissue concentration of juvenile brown trout was about 10 times higher than the muscle tissue concentration of brown trout larvae possibly based on a more intense citalopram uptake due to the ongoing development of the gastro-intestinal system and/or gills of larvae. Sackerman et al. (2010) showed a bioconcentration of $115 \pm 37 \mathrm{ng} / \mathrm{g}$ citalopram in the 
436 brain and $193 \pm 33 \mathrm{ng} / \mathrm{g}$ in the muscle tissue of zebrafish exposed to $24.3 \mu \mathrm{g} / \mathrm{L}$ for only 3

437 minutes. Brown trout exposed to an effluent-dominated stream (citalopram water concentrations:

$4384.5-58 \mathrm{ng} / \mathrm{L}$ ) in the Czech Republic showed citalopram concentrations up to $31 \pm 11 \mathrm{ng} / \mathrm{g}$ in liver

439 and $164 \pm 19 \mathrm{ng} / \mathrm{g}$ in kidney tissue; however, no citalopram could be detected in brain and

440 muscle tissue (Grabicova et al. 2017). Likewise, rainbow trout exposed to the effluent of a

441 Swedish wastewater treatment plant (citalopram water concentration: $260 \pm 60 \mathrm{ng} / \mathrm{L}$ ) had most

442 citalopram in the liver and brain, with concentrations of $12 \pm 5 \mathrm{ng} / \mathrm{g}$ and $2.2 \pm 1.3 \mathrm{ng} / \mathrm{g}$,

443 respectively. In contrast, no citalopram was detected in plasma and muscle tissue (Grabicova et

444 al. 2014). The reason for finding citalopram being accumulated in muscle tissue in our study

445 might either be due to the fact that the exposure time was longer and the test concentrations were

446 higher than those used in other studies (Grabicova et al. 2017; Grabicova et al. 2014; Sackerman

447 et al. 2010) or result from a diverging accumulation pattern in brown trout compared to other fish

448 species (Du et al. 2016).

\section{Mortality}

450 Mortality of larvae and juvenile fish was not influenced by citalopram exposure. Although the

451 overall mortality increased to $29 \%$ in brown trout larvae exposed at $11^{\circ} \mathrm{C}$. This higher mortality

452 relates to the fact that brown trout larvae exposed to $11^{\circ} \mathrm{C}$ had a higher metabolism and that the

453 beginning of exogenous feeding in salmonids is associated with higher mortality risks

454 (Klemetsen et al. 2003). Also in a study by Kellner et al. (2016), in which sticklebacks have been

455

456

457 exposed for 21 days to 1.5 and $15 \mu \mathrm{g} / \mathrm{L}$ citalopram, no differences in mortality were found. Likewise, time to hatch was not affected by citalopram. This is in accordance with other studies that did not reveal differences in hatching success and time for zebrafish or Japanese medaka exposed to the SSRI fluoxetine (Foran et al. 2004; Wu et al. 2017). With regard to the

459 developmental parameter heart rate of brown trout larvae, no effect was seen in fish exposed to either temperature and any citalopram concentration corroborating finding for other SSRIs by Airhart et al. (2007), who exposed zebrafish larvae to $1,39 \mathrm{mg} / \mathrm{L}$ of the SSRI fluoxetine.

\section{Fish growth}

463 In our experiment, we visually observed more food leftovers in the exposure tanks with 1000 $\mu \mathrm{g} / \mathrm{L}$ citalopram, which allowed us to conclude that there was a lower food intake in fish exposed to $1000 \mu \mathrm{g} / \mathrm{L}$ citalopram; however, a quantification of this effect was not possible. Known side effects of citalopram are anorexia and weight loss in humans (Information of HEXAL (2012)) and published data on fish revealed a decreased food intake in sticklebacks exposed to $0.15 \mu \mathrm{g} / \mathrm{L}$ citalopram (Kellner et al. 2015). Reduced food intake in fish was also shown for two other antidepressants, sertraline and fluoxetine, in European perch and goldfish (Hedgespeth et al. 2014; Mennigen et al. 2010). In contrast three-spined stickleblacks exposed for 30 days to 1,5 $\mu \mathrm{g} / \mathrm{L}$ citalopram with a subsequent 185 days recovery phase showed increased attacks on a chironomid larvae (Kellner et al. 2017). Mechanistically, the increased swimming activity and the conceivably decreased food intake of the fish make the observed decrease in weight and length of the fish exposed to $1000 \mu \mathrm{g} / \mathrm{L}$ citalopram is reasonable to result from exposure to citalopram, especially as exposed fish were in a period of intense growth. Decreased weight has also been shown in goldfish and decreased length in zebrafish exposed to 54 and $10 \mu \mathrm{g} / \mathrm{L}$ of the SSRI fluoxetine, respectively (Mennigen et al. 2010; Wu et al. 2017). 


\section{Behaviour during exposure}

479 Control brown trout preferably stayed at the bottom of the tank when kept in the exposure tanks

480

481

482

483

484

485

486

487

488

489

490

491

492

493

494

495

496

497

498

499

500

501

502

503

504

505

506

507

508

509

510

511

512

513

514

515

516

517

518

519

520
(Table 1 and 2). Fish exposed to $1000 \mu \mathrm{g} / \mathrm{L}$ citalopram showed an increased preference for the upper half of the aquaria independent of their life stage. In general, the test design used in the present study for this parameter implies parts of the novel tank diving test, the scototaxis test and shoaling. Stewart et al. (2012) described the novel tank diving test for the measurement of anxiety, where single zebrafish are placed in tanks. Time spent in the upper aquaria portion is recorded along with other parameters like the number of transitions into the upper aquaria portion or number of freezing bouts. When the fish in a novel tank stay in the lower aquaria part (geotaxis) it is a sign for anxiety behaviour and in contrast the transition into the upper aquaria part is a sign of boldness and therefore anti-anxiety behaviour (Stewart et al. 2012). Maximino et al. (2010) described the scototaxis test, where fish are transposed into a novel tank and can freely swim into the dark or bright zone. Preferring the dark part of the aquaria and avoiding the brighter side is a clear sign of anxiety (Maximino et al. 2010). Furthermore, Stewart et al. (2012) described fish with lower anxiety to have a greater tendency to break away from the shoal in zebrafish. It is obvious that in our case swimming behaviour of the shoal of brown trout was assessed and not individual swimming behaviour. Therefore, the stressor not being in a shoal, like in the novel tank and scototaxis test is not present in our case. Additionally, brown trout were not transposed into novel tanks, but the tanks were covered the most of the exposure time with black foil, only when the photos were taken, the foil was removed, which lead to a higher illumination from the top. Overall an increased stay in the upper aquaria part is a preference for the brighter illuminated water column and water surface in contrast to the darker aquaria bottom. Additionally, these fish recede from the shoal at the bottom of the tank. In our experiments, up to $80 \%$ brown trout larvae and $25 \%$ of juveniles exposed to $1000 \mu \mathrm{g} / \mathrm{L}$ citalopram stayed in the upper aquaria section compared to the control animal. This can be explained by decreased anxiety and an altered swimming behaviour characterised by a higher activity of the exposed fish (Maximino et al. 2010; Stewart et al. 2012). The stronger effect of citalopram on the vertical distribution of the brown trout larvae can be explained by a 5 times longer exposure time compared to the juvenile individuals. Also, different sensitivities of the life stages can come into play, and has already be shown for diclofenac (Schwarz et al. 2017). The significant difference in time spent in the upper aquaria part of the brown trout larvae exposed to $1 \mu \mathrm{g} / \mathrm{L}$ citalopram at $7^{\circ} \mathrm{C}$ could also be due to the fact that only one of the three replicate aquaria was photographed and therefore a single individual has a higher impact on the relative number spent in the upper aquaria part. For this reason and the inherent variation in this setup for behaviour measurement the biological relevance of the slight effect in the 1 and $10 \mu \mathrm{g} / \mathrm{L}$ treatment has to be confirmed with a bigger sample size. An anxiolytic effect of citalopram in the novel tank test was also shown for other fish species like Endler's guppies, three-spined sticklebacks and zebrafish, even at decidedly lower concentrations of citalopram down to $1.5 \mu \mathrm{g} / \mathrm{L}$, which all spent more time in the upper aquaria part during the novel tank test (Kellner et al. 2016; Olsen et al. 2014; Sackerman et al. 2010). Furthermore, Kellner et al. (2017) discovered increased transitions to the bright side in sticklebacks exposed to $1,5 \mu \mathrm{g} / \mathrm{L}$ citalopram for 30 days with subsequent 120 days recovery phase. But latency to first transition and time spent in the brighter zone was not influenced. Also sticklebacks exposed did not show any difference to control fish in the novel

Peer) reviewing PDF | (2019:12:43947:2:1:NEW 14 Feb 2020) 
521 tank test, except for decreased acitivty (Kellner et al. 2017). Kellner et al. (2016) also observed

522

523

524

525

526

527

528

529

530

531

532

533

534

535

536

537

538

539

540

541

542

543

544

545

546

547

548

549

550

551

552

553

554

555

556

557

558

559

560

561

562

563

increased swimming activity in fish exposed to $1.5 \mu \mathrm{g} / \mathrm{L}$ citalopram. This effect has not only been shown in response to citalopram but has also been found for other antidepressants like fluoxetine or amitriptyline, which seem to reduce anxiety and increase the stay of the fish in the upper part of the aquarium (Demin et al. 2017; Henry \& Black 2008; Meshalkina et al. 2018)..

\section{Behaviour in a stressful environment and cortisol measurements}

In contrast to the increased swimming activity under minor stress conditions, brown trout larvae exposed to citalopram showed a decreased swimming activity in the stressful artificial swimming measurement device (ASMD). This effect can be due to the anxiolytic and soothing effect of the antidepressant. Based on the measurements of the tissue cortisol level, it is evident that the ASMD creates a rather stressful environment for the fish (Figure 2) (Wendelaar Bonga 1997). The transfer of fish into an ASMD leads to a stress reaction in larvae. This stress reaction is characterised by freezing behaviour at the beginning followed up by increased velocity and escape behaviour (Figure 1). Having a look on the time dependant velocity and time of no movement, it is clear that the control larvae are swimming faster and have reduced time of no movements over recording. In contrast larvae exposed to $1 \mathrm{mg} / \mathrm{L}$ citalopram do not show this pattern, but have a constant low mean velocity and longer time of no movement over the total recording time. A similar pattern can be seen in fish exposed to $100 \mu \mathrm{g} / \mathrm{L}$ citalopram but not as distinct as in fish exposed to $1 \mathrm{mg} / \mathrm{L}$. Since citalopram is an anxiolytic drug and reduces anxiety, fish are reasonably soothed when exposed to $100 \mu \mathrm{g} / \mathrm{L}$ or $1000 \mu \mathrm{g} / \mathrm{L}$ citalopram as they swam slower than control fish over the total recording time. Therefore, the total distance they moved and their mean swimming velocity were lower than that of the controls. Additionally, the time dependant behaviour pattern is not given in fish exposed to $1 \mathrm{mg} / \mathrm{L}$ citalopram. It is also possible the reduced mean velocity and increased time of no movement is due to a sedative effect of the antidepressant. Furthermore, it cannot be excluded, that the increased time of no movement of fish exposed to $1 \mathrm{mg} / \mathrm{L}$ citalopram represents freezing and therefore anxiogenic behaviour. Nevertheless, with regard to the results of the behaviour during the exposure, it is more likely that the effect is due to a reduction of anxiety in brown trout larvae which resulted in calmed behaviour. This reduction in activity due to citalopram in the ASMD could not be seen in juvenile fish. Neither total distance moved nor the pattern over time differed between the treatment and the control animals. Nevertheless, the total distance moved and the mean velocity of swimming in all citalopram-treated juveniles was $70 \%$ lower than in controls, but these differences were not significant. Similar to the effect on citalopram on vertical distribution patterns during exposure, behavioral changes in the ASMD were more pronounced in exposed larvae than in juveniles. As previously mentioned this might be the result of the longer exposure of larvae or different sensitivities between life stages (Schwarz et al. 2017). It has been reported previously that antidepressants reduce swimming activity. Three-spined sticklebacks exposed to $1,5 \mu \mathrm{g} / \mathrm{L}$ citalopram for 30 days at a developmental stage with subsequent 160 days recovery phase showed a decrease in swimming activity (Kellner et al. 2017). Zebrafish embryos exposed to either $1 \mathrm{mg} / \mathrm{L}$ venlafaxine or $3 \mathrm{mg} / \mathrm{L}$ sertraline showed reduced swimming behaviour in the zebrabox (Sehonova et al. 2019). With regard to the sedative effect of antidepressants, for example, western mosquitofish exposed to $0.5 \mu \mathrm{g} / \mathrm{L}$ fluoxetine over 91 days showed increased lethargy similar to fish exposed to $53 \mu \mathrm{g} / \mathrm{L}$ for 7 days (Henry \& Black 2008). Furthermore,

Peer) reviewing PDF | (2019:12:43947:2:1:NEW 14 Feb 2020) 
564 guppies exposed to $16 \mathrm{ng} / \mathrm{L}$ fluoxetine for 28 days showed increased freezing time and time

565

566

567

568

569

570

571

572

573

574

575

576

577

578

579

580

581

582

583

584

585

586

587

588

589

590

591

592

593

594

595

596

597

598

599

600

601

602

603

604

605

spent under cover (Saaristo et al. 2017). Male bluehead wrasse injected intraperitoneal with 6 $\mu \mathrm{g} / \mathrm{g}$ bw fluoxetine showed decreased activity levels (Perreault et al. 2003). But also meagre exposed to $20 \mu \mathrm{g} / \mathrm{L}$ venlafaxine showed reduced swimming activity (Maulvault et al. 2018). But it could also be shown that antidepressants reduces anxiety in exposed fish: Painter et al. (2009) showed a decreased escape behaviour in fathead minnow larvae exposed to $250 \mathrm{ng} / \mathrm{L}$ of the SSRI fluoxetine, resulting in reduced swimming velocity. Likewise, fathead minnow larvae exposed to the serotonin and noradrenalin reuptake inhibitor (SNRI) venlafaxine revealed reduced anxiety, indicated by a reduced escape response (Painter et al. 2009).

\section{Calculated plasma concentrations}

Therapeutic human plasma concentrations in patients treated with doses of $20-60 \mathrm{mg}$ citalopram per day are $117 \pm 95 \mu \mathrm{g} / \mathrm{L}$ (Le Bloc'h et al. 2003). In contrast, Schreiber et al. (2011) reported a maximum blood plasma concentration of only $21.1 \mu \mathrm{g} / \mathrm{L}$ in patients after drug administration with a maximum daily dose of $60 \mathrm{mg}$. Considering measured human therapeutic plasma concentrations of citalopram, calculated plasma concentrations in fish exposed to $1,10,100$ and $1000 \mu \mathrm{g} / \mathrm{L}$ at pH 8 with the fish plasma model (Supplement, Table 8) (Fu et al. 2009; Huggett et al. 2003; Schreiber et al. 2011) revealed that the calculated concentrations in fish exposed to 100 $\mu \mathrm{g} / \mathrm{L}$ citalopram or higher exceeded the human therapeutic plasma concentrations according to Le Bloc'h et al. (2003). When referred to the human plasma concentrations in the study conducted by Schreiber et al. (2011), when even exposed to $10 \mu \mathrm{g} / \mathrm{L}$ fish plasma concentrations would exceed the concentrations in human plasma. However, Holmberg et al. (2011) showed that 2 out of 5 rainbow trout exposed to $10 \mu \mathrm{g} / \mathrm{L}$ citalopram revealed a plasma citalopram concentration of $0.044 \mu \mathrm{g} / \mathrm{L}$ and $0.08 \mu \mathrm{g} / \mathrm{L}$ after exposure for only $24 \mathrm{~h}$. The lack of behavioural effects in the study of Holmberg et al. (2011) and also our results obtained for the lower treatments $1 \mu \mathrm{g} / \mathrm{L}$ and $10 \mu \mathrm{g} / \mathrm{L}$ citalopram, suggests that citalopram plasma concentrations in fish below human therapeutic plasma concentrations do not to affect the fish. Though, our results on behaviour and growth of brown trout provide evidence that citalopram plasma concentrations in fish higher than human therapeutic plasma concentrations can have severe impact on brown trout in different life stages.

\section{Conclusion}

Our results clearly show that citalopram affects brown trout according to its mode of action known for humans. Under stressful conditions, fish showed reduced swimming behaviour when exposed to at least $100 \mu \mathrm{g} / \mathrm{L}$ citalopram. Furthermore, in the exposure tanks, an increased swimming activity during exposure was observed for fish exposed to $1 \mathrm{mg} / \mathrm{L}$ citalopram, which can be linked to the anti-depressant effect of the drug. The behavioural changes were stronger in early life stages, which could be associated with the longer exposure time in larvae compared to juveniles, but also differences in sensitivity between life stages may play a role. In addition, sideeffects of the antidepressant known from human applications could be detected, like reduced weight and length, in both juvenile brown trout and brown trout larvae exposed to $1000 \mu \mathrm{g} / \mathrm{L}$ citalopram. Our results confirm similar findings for citalopram exposure to those reported for other aquatic species. To conclude, citalopram, as a widely distributed drug, severely alters the behaviour and growth of brown trout in different life stages, at concentrations higher than current 
606

607

608

609

610

611

612

613

614

615

616

617

618

619

620

621

622

623

624

625

626

627

628

629

630

631

632

633

634

635

636

637

638

639

640

641

642

643

644

645

646

647

648

environmentally relevant levels. And the 10 times stronger accumulation of citalopram in juveniles makes evident that an increase in surface water concentration of citalopram could have severe impact on specific life stages of fish. Nevertheless, considering safety factors up to $10^{3}$ that have to be included in environmental risk assessment and also additive effects of pharmaceuticals affecting similar pathways, citalopram is far from being an environmentally safe pharmaceutical and has to be considered carefully with respect to risk for the aquatic environment.

\section{Acknowledgements}

This study is part of the project Effect-Net (Effect Network in Water Research), which is part of the Water Research Network Baden-Württemberg (Wassernetzwerk Baden-Württemberg) and funded by the Ministry for Science, Research and Arts of Baden-Württemberg. Carolin Huhn thanks for the support from the Excellence Initiative, a jointly funded program of the German Federal and State governments, organized by the German Research Foundation (DFG). We thank the Open Access Publishing Fund of University of Tübingen for support. Particular thanks go to Thomas Braunbeck, Heidelberg University, for the coordination of this project. Furthermore, the authors thank Stefanie Jacob, Stefanie Krais, Elisabeth May, Katharina Peschke, Lukas Reinelt, Hannah Schmieg and Sabrina Wilhelm for help in the laboratory and technical assistance, and Stefanie Dietz for comments on the manuscript. Futhermore, thanks go to Nils Anthes and Simon Schwarz for statistical advice. Language check was conducted by Proof-Reading-Service.com.

\section{References}

Acuna V, von Schiller D, Garcia-Galan MJ, Rodriguez-Mozaz S, Corominas L, Petrovic M, Poch M, Barcelo D, and Sabater S. 2015. Occurrence and in-stream attenuation of wastewater-derived pharmaceuticals in Iberian rivers. Science of the Total Environment 503-504:133-141. 10.1016/j.scitotenv.2014.05.067

Airhart MJ, Lee DH, Wilson TD, Miller BE, Miller MN, and Skalko RG. 2007. Movement disorders and neurochemical changes in zebrafish larvae after bath exposure to fluoxetine (PROZAC). Neurotoxicology and Teratology 29:652-664. 10.1016/j.ntt.2007.07.005

Alvarez-Munoz D, Rodriguez-Mozaz S, Maulvault AL, Tediosi A, Fernandez-Tejedor M, Van den Heuvel F, Kotterman M, Marques A, and Barcelo D. 2015. Occurrence of pharmaceuticals and endocrine disrupting compounds in macroalgaes, bivalves, and fish from coastal areas in Europe. Environmental Research 143:56-64. 10.1016/j.envres.2015.09.018

aus der Beek T, Grüttner G, and Carius A. 2016. Pharmaceuticals in the environment: Global occurence and potential cooperative action under the Strategic Appoach to International Chemicals Management (SAICM). In: Agency GE, editor. Dessau-Roßlau: German Environment Agency.

Demin KA, Kolesnikova TO, Khatsko SL, Meshalkina DA, Efimova EV, Morzherin YY, and Kalueff AV. 2017. Acute effects of amitriptyline on adult zebrafish: Potential relevance to antidepressant drug screening and modeling human toxidromes. Neurotoxicology and Teratology 62:27-33. 10.1016/j.ntt.2017.04.002

Destatis. 2017. Gesundheit: Diagnosedaten der Patienten und Patientinnen in Krankenhäusern (einschl. Sterbe- und Stundenfälle) 2016. In: Bundesamt S, editor: Statistisches Bundesamt.

Du B, Haddad SP, Luek A, Scott WC, Saari GN, Burket SR, Breed CS, Kelly M, Broach L, Rasmussen JB, Chambliss CK, and Brooks BW. 2016. Bioaccumulation of human pharmaceuticals in fish across 
649

650

651

652

653

654

655

656

657

658

659

660

661

662

663

664

665

666

667

668

669

670

671

672

673

674

675

676

677

678

679

680

681

682

683

684

685

686

687

688

689

690

691

692

693

694

695

habitats of a tidally influenced urban bayou. Environmental Toxicology and Chemistry 35:966-974. 10.1002/etc.3221

Fick J, Lindberg RH, Tysklind M, and Larsson DG. 2010. Predicted critical environmental concentrations for 500 pharmaceuticals. Regulatory Toxicology and Pharmacology 58:516-523. 10.1016/j.yrtph.2010.08.025

Fick J, Söderström H, Lindberg RH, Phan C, Tysklind M, and Larsson DGJ. 2009. Contamination of surface, ground, and drinking water from pharmaceutical production. Environmental Toxicology and Chemistry 28:2522-2527. 10.1897/09-073.S1

Foran CM, Weston J, Slattery M, Brooks BW, and Huggett DB. 2004. Reproductive Assessment of Japanese Medaka (Oryzias latipes) Following a Four-Week Fluoxetine (SSRI) Exposure. Archives of Environmental Contamination and Toxicology 46. 10.1007/s00244-003-3042-5

Fu W, Franco A, and Trapp S. 2009. Methods for estimating the bioconcentrations factor of ionizable organic chemicals. Environmental Toxicology and Chemistry 28:8.

Grabicova K, Grabic R, Fedorova G, Fick J, Cerveny D, Kolarova J, Turek J, Zlabek V, and Randak T. 2017. Bioaccumulation of psychoactive pharmaceuticals in fish in an effluent dominated stream. Water Research 124:654-662. 10.1016/j.watres.2017.08.018

Grabicova K, Lindberg RH, Ostman M, Grabic R, Randak T, Larsson DG, and Fick J. 2014. Tissue-specific bioconcentration of antidepressants in fish exposed to effluent from a municipal sewage treatment plant. Science of the Total Environment 488-489:46-50. 10.1016/j.scitotenv.2014.04.052

Gunnarsson L, Jauhainen A, Kristiansson E, Nerman O, and Larsson DGJ. 2008. Evolutionary Consevation of Human Drufg Targets in Organisms used for Environmental Risk Assessments. Environmental Science \& Technology 42:5807-5813. 10.1021/es8005173

Hedgespeth ML, Nilsson PA, and Berglund O. 2014. Ecological implications of altered fish foraging after exposure to an antidepressant pharmaceutical. Aquatic Toxicology 151:84-87. 10.1016/j.aquatox.2013.12.011

Henry TB, and Black MC. 2008. Acute and chronic toxicity of fluoxetine (selective serotonin reuptake inhibitor) in western mosquitofish. Archives of Environmental Contamination and Toxicology 54:325-330. 10.1007/s00244-007-9018-0

HEXAL. 2012. Citalopram HEXAL $10 \mathrm{mg}$ Filmtabletten. Available at https://www.medikamente-perklick.de/images/ecommerce/01/39/01390871 2012-05 de 0.pdf (accessed 04.06.2019 2019).

Himmelsbach M, Buchberger W, and Klampfl CW. 2006. Determination of antidepressants in surface and waste water samples by capillary electrophoresis with electrospray ionization mass spectrometric detection after preconcentration using off-line solid-phase extraction. Electrophoresis 27:12201226. 10.1002/elps.200500693

Holmberg A, Fogel J, Albertsson E, Fick J, Brown JN, Paxeus N, Forlin L, Johnsson JI, and Larsson DG. 2011. Does waterborne citalopram affect the aggressive and sexual behaviour of rainbow trout and guppy? Journal of Hazardous Materials 187:596-599. 10.1016/j.jhazmat.2011.01.055

Huggett DB, Cook JC, Ericson JF, and Williams RT. 2003. A Theoretical Model for Utilizing Mammalian Pharmacology and Safety Data to Prioritize Potential Impacts of Human Pharmaceuticals to Fish. Human and Ecological Risk Assessment: An International Journal 9:1789-1799. 10.1080/714044797

Hughes SR, Kay P, and Brown LE. 2013. Global synthesis and critical evaluation of pharmaceutical data sets collected from river systems. Environmental Science \& Technology 47:661-677. 10.1021/es3030148

Hyttel J. 1994. Pharmacological characterization of selective serotonin reuptake inhibitors (SSRIs). Int Clin Psychopharmacol 9 Suppl 1:19-26. 
696

697

698

699

700

701

702

703

704

705

706

707

708

709

710

711

712

713

714

715

716

717

718

719

720

721

722

723

724

725

726

727

728

729

730

731

732

733

734

735

736

737

738

739

740

741

742

743
Kellner M, Porseryd T, Hallgren S, Porsch-Hallstrom I, Hansen SH, and Olsen KH. 2016. Waterborne citalopram has anxiolytic effects and increases locomotor activity in the three-spine stickleback (Gasterosteus aculeatus). Aquatic Toxicology 173:19-28. 10.1016/j.aquatox.2015.12.026

Kellner M, Porseryd T, Porsch-Hallstrom I, Borg B, Roufidou C, and Olsen KH. 2017. Developmental exposure to the SSRI citalopram causes long-lasting behavioural effects in the three-spined stickleback (Gasterosteus aculeatus). Ecotoxicology 27:12-22. 10.1007/s10646-017-1866-4

Kellner M, Porseryd T, Porsch-Hallstrom I, Hansen SH, and Olsen KH. 2015. Environmentally relevant concentrations of citalopram partially inhibit feeding in the three-spine stickleback (Gasterosteus aculeatus). Aquatic Toxicology 158:165-170. 10.1016/j.aquatox.2014.11.003

Keysomi MME, Sudagar M, and Asl N. 2013. Effect of Citalopram on Reducing Transportation Stress in Rainbow Trout (Oncorhynchus mykiss). Journal of Aquaculture Research \& Development 04. 10.4172/2155-9546.1000171

Klemetsen A, Amundsen P-A, Dempson JB, Jonsson B, Jonsson N, O'Connell MF, and Mortensen E. 2003. Atlanic salmon Salmo salar L., brown trout Salmo trutta L. and arctic charr Salvelinus alpinus (L.): a review of aspects of their life histories. Ecology of Freshwater Fish 12:1-59.

Larsson DG, de Pedro C, and Paxeus N. 2007. Effluent from drug manufactures contains extremely high levels of pharmaceuticals. Journal of Hazardous Materials 148:751-755. 10.1016/j.jhazmat.2007.07.008

Le Bloc'h Y, Brigitte W, Weissenrieder H, Brawand-Amey M, Spagnoli J, Eap CB, and Baumann P. 2003. Routine Therapeutic Drug Monitoring in Patients Treated with 10-360 mg/day Citalopram. Therapeutic Drug Monitoring 25:600-608.

Martin JM, Saaristo M, Bertram MG, Lewis PJ, Coggan TL, Clarke BO, and Wong BBM. 2017. The psychoactive pollutant fluoxetine compromises antipredator behaviour in fish. Environmental Pollution 222:592-599. 10.1016/j.envpol.2016.10.010

Maulvault AL, Santos L, Paula JR, Camacho C, Pissarra V, Fogaca F, Barbosa V, Alves R, Ferreira PP, Barcelo D, Rodriguez-Mozaz S, Marques A, Diniz M, and Rosa R. 2018. Differential behavioural responses to venlafaxine exposure route, warming and acidification in juvenile fish (Argyrosomus regius). Science of the Total Environment 634:1136-1147. 10.1016/j.scitotenv.2018.04.015

Maximino C, Marques de Brito T, Dias CA, Gouveia A, Jr., and Morato S. 2010. Scototaxis as anxiety-like behavior in fish. Nat Protoc 5:209-216. 10.1038/nprot.2009.225

Mennigen JA, Sassine J, Trudeau VL, and Moon TW. 2010. Waterborne fluoxetine disrupts feeding and energy metabolism in the goldfish Carassius auratus. Aquatic Toxicology 100:128-137. 10.1016/j.aquatox.2010.07.022

Meshalkina DA, Kysil EV, Antonova KA, Demin KA, Kolesnikova TO, Khatsko SL, Gainetdinov RR, Alekseeva PA, and Kalueff AV. 2018. The Effects of Chronic Amitriptyline on Zebrafish Behavior and Monoamine Neurochemistry. Neurochemical Research. 10.1007/s11064-018-2536-5

Moermond CT, Kase R, Korkaric M, and Agerstrand M. 2016. CRED: Criteria for reporting and evaluating ecotoxicity data. Environmental Toxicology and Chemistry 35:1297-1309. 10.1002/etc.3259

Nodler K, Licha T, Bester K, and Sauter M. 2010. Development of a multi-residue analytical method, based on liquid chromatography-tandem mass spectrometry, for the simultaneous determination of 46 micro-contaminants in aqueous samples. J Chromatogr A 1217:6511-6521. 10.1016/j.chroma.2010.08.048

Olsen KH, Ask K, Olsen H, Porsch-Hallstrom I, and Hallgren S. 2014. Reprint of "Effects of the SSRI citalopram on behaviours connected to stress and reproduction in Endler guppy, Poecilia wingei". Aquatic Toxicology 151:97-104. 10.1016/j.aquatox.2014.02.011

Paiga P, Santos L, Ramos S, Jorge S, Silva JG, and Delerue-Matos C. 2016. Presence of pharmaceuticals in the Lis river (Portugal): Sources, fate and seasonal variation. Science of the Total Environment 573:164-177. 10.1016/j.scitotenv.2016.08.089

Peer] reviewing PDF | (2019:12:43947:2:1:NEW 14 Feb 2020) 
Painter MM, Buerkley MA, Julius ML, Vajda AM, Norris DO, Barber LB, Furlong ET, Schultz MM, and Schoenfuss H. 2009. Antidepressants at environmentally relevant concentraitions affect predator avoidance behaviour of larval fathead minnows (Pimephales promelas). Environmental Toxicology and Chemistry 28:2677-2684. 0730-7268/09

Perreault H, Semsar K, and Godwin J. 2003. Fluoxetine treatment decreases territorial aggression in a coral reef fish. Physiology \& Behavior 79:719-724. 10.1016/s0031-9384(03)00211-7

Saaristo M, McLennan A, Johnstone CP, Clarke BO, and Wong BBM. 2017. Impacts of the antidepressant fluoxetine on the anti-predator behaviours of wild guppies (Poecilia reticulata). Aquatic Toxicology 183:38-45. 10.1016/j.aquatox.2016.12.007

Sackerman J, Donehan JJ, Cunningham CS, Nguyen NN, Lawless K, Long A, Benno RH, and Gould GG. 2010. Zebrafish behaviour in Novel Environments: Effecrs of Acute Exposure to Anxiolytic Compunds and Choice of Danio rerio Line. International Journal of Comparative Psychology 23:43-61.

Schreiber R, Gundel U, Franz S, Kuster A, Rechenberg B, and Altenburger R. 2011. Using the fish plasma model for comparative hazard identification for pharmaceuticals in the environment by extrapolation from human therapeutic data. Regulatory Toxicology and Pharmacology 61:261275. 10.1016/j.yrtph.2011.08.006

Schultz MM, Furlong ET, Kolpin DW, Werner SL, Schoenfuss HL, Barber LB, Blazer VS, Norris DO, and Vaida AM. 2010. Antidepressant Pharmaceuticals in Two U.S. Effluent-Impacted Streams: Occurence and Fate in Water and Sediment, and Selective Uptake in Fish Neural Tissue. Environmental Science \& Technology 44:1918-1925. 10.1021/es9022706

Schwabe U, and Paffrath D. 2016. Arzneiverordnungs-Report 2016: Aktuelle Daten, Kosten, Trends und Kommentare. Berlin, Heidelberg: Springer Berlin Heidelberg.

Schwarz S, Schmieg H, Scheurer M, Kohler HR, and Triebskorn R. 2017. Impact of the NSAID diclofenac on survival, development, behaviour and health of embryonic and juvenile stages of brown trout, Salmo trutta f. fario. Science of the Total Environment 607-608:1026-1036. 10.1016/j.scitotenv.2017.07.042

Sehonova P, Hodkovicova N, Urbanova M, Orn S, Blahova J, Svobodova Z, Faldyna M, Chloupek P, Briedikova K, and Carlsson G. 2019. Effects of antidepressants with different modes of action on early life stages of fish and amphibians. Environmental Pollution 254:112999. 10.1016/j.envpol.2019.112999

Silva L, Pereira AM, Meisel LM, Lino CM, and Pena A. 2014. A one-year follow-up analysis of antidepressants in Portuguese wastewaters: occurrence and fate, seasonal influence, and risk assessment. Science of the Total Environment 490:279-287. 10.1016/j.scitotenv.2014.04.131

Stewart A, Gaikwad S, Kyzar E, Green J, Roth A, and Kalueff AV. 2012. Modeling anxiety using adult zebrafish: a conceptual review. Neuropharmacology 62:135-143. 10.1016/j.neuropharm.2011.07.037

Vasskog T, Berger U, Samuelsen PJ, Kallenborn R, and Jensen E. 2006. Selective serotonin reuptake inhibitors in sewage influents and effluents from Tromso, Norway. J Chromatogr A 1115:187-195. 10.1016/j.chroma.2006.02.091

Verbruggen B, Gunnarsson L, Kristiansson E, Osterlund T, Owen SF, Snape JR, and Tyler CR. 2018. ECOdrug: a database connecting drugs and conservation of their targets across species. Nucleic Acids Research 46:D930-D936. 10.1093/nar/gkx1024

Wendelaar Bonga SEW. 1997. The Stress Response in Fish. Physiological Reviews 77:592-616.

Wu M, Liu S, Hu L, Qu H, Pan C, Lei P, Shen Y, and Yang M. 2017. Global transcriptomic analysis of zebrafish in response to embryonic exposure to three antidepressants, amitriptyline, fluoxetine and mianserin. Aquatic Toxicology 192:274-283. 10.1016/j.aquatox.2017.09.027

PeerJ reviewing PDF | (2019:12:43947:2:1:NEW 14 Feb 2020) 


\section{Table 1 (on next page)}

Results for brown trout larvae exposed to citalopram.

Data are shown as arithmetical means \pm standard deviation. Asterisks represent significant differences to the respective control $\left(* p<0.05 ;{ }^{* *} p<0.01 ;{ }^{* * *} p<0.001\right)$. Abbreviations: n.a. $=$ not assessed; $d p f=$ day post-fertilisation; LoD=limit of detection. 
1 Table 1:

2 Results for brown trout larvae exposed to citalopram.

3 Data are shown as arithmetical means \pm standard deviation. Asterisks represent significant differences to the respective control

$4 \quad\left({ }^{*} p<0.05 ;{ }^{*} p<0.01 ; *^{*} p<0.001\right)$. Abbreviations: $n . a .=$ not assessed; $d p f=$ day post-fertilisation; LoD=limit of detection

\begin{tabular}{|c|c|c|c|c|c|c|c|c|c|c|}
\hline Temperature & \multicolumn{5}{|l|}{$11^{\circ} \mathrm{C}$} & \multicolumn{5}{|l|}{$7^{\circ} \mathrm{C}$} \\
\hline Treatment $(\mu \mathrm{g} / \mathrm{L})$ & 0 & 1 & 10 & 100 & 1000 & 0 & 1 & 10 & 100 & 1000 \\
\hline Mortality (\%) & $\begin{array}{l}6.67 \\
2.72\end{array}$ & $\begin{array}{l}32.22 \\
\pm 1.57\end{array}$ & \begin{tabular}{|l}
28.89 \\
\pm 8.75
\end{tabular} & $\begin{array}{l}35.56 \\
\pm 4.16\end{array}$ & $\begin{array}{l}22.22 \pm \\
3.14\end{array}$ & $\begin{array}{l}2.22 \pm \\
3.14\end{array}$ & $\begin{array}{l}4.44 \pm \\
4.16\end{array}$ & $\begin{array}{l}3.37 \pm \\
2.72\end{array}$ & $\begin{array}{l}6.74 \pm \\
2.72\end{array}$ & $\begin{array}{ll}6.67 & \pm \\
2.72 & \end{array}$ \\
\hline Weight (g) & $\begin{array}{l}0.449 \\
\pm \\
0.139 \\
\end{array}$ & $\begin{array}{l}0.484 \\
\pm \\
0.169 \\
\end{array}$ & \begin{tabular}{|l}
0.447 \\
\pm \\
0.140 \\
\end{tabular} & $\begin{array}{l}0.487 \\
\pm \\
0.143 \\
\end{array}$ & $\begin{array}{l}0.306 \pm \\
0.146 \\
* * *\end{array}$ & $\begin{array}{l}0.327 \\
\pm \\
0.089 \\
\end{array}$ & $\begin{array}{l}0.413 \\
\pm \\
0.113 \\
\end{array}$ & \begin{tabular}{|l}
0.335 \\
\pm \\
0.101 \\
\end{tabular} & \begin{tabular}{|l}
0.337 \\
\pm \\
0.091 \\
\end{tabular} & $\begin{array}{l}0.247 \pm \\
0.066 \\
* * * \\
\end{array}$ \\
\hline Length $(\mathrm{cm})$ & $\begin{array}{l}3.76 \pm \\
0.37\end{array}$ & $\begin{array}{l}3.83 \pm \\
0.42\end{array}$ & $\begin{array}{l}3.73 \pm \\
0.39\end{array}$ & $\begin{array}{l}3.74 \pm \\
0.40\end{array}$ & $\begin{array}{l}3.24 \quad \pm \\
0.43 \\
* * *\end{array}$ & $\begin{array}{l}3.33 \pm \\
0.27\end{array}$ & $\begin{array}{l}3.38 \pm \\
0.32\end{array}$ & $\begin{array}{l}3.30 \pm \\
0.32\end{array}$ & $\begin{array}{l}3.25 \pm \\
0.28\end{array}$ & $\begin{array}{ll}2.91 & \pm \\
0.23 & \\
* * * & \end{array}$ \\
\hline Heart rate (bpm) & 74 & n.a. & n.a. & n.a. & \begin{tabular}{|ll}
75 & \pm \\
4.52 & \\
\end{tabular} & $\begin{array}{l}49.93 \\
\pm 1.5 \\
\end{array}$ & \begin{tabular}{|l}
$51.8 \pm$ \\
3.19 \\
\end{tabular} & \begin{tabular}{|l}
$49.2 \pm$ \\
3.25 \\
\end{tabular} & $\begin{array}{ll}50 & \pm \\
3.03\end{array}$ & $\begin{array}{ll}49 & \pm \\
2.37 & \\
\end{array}$ \\
\hline Time to hatch (dpf) & $\begin{array}{l}49.69 \\
\pm 0.93 \\
\end{array}$ & $\begin{array}{r}49.64 \\
\pm 1.11 \\
\end{array}$ & \begin{tabular}{|l}
49.74 \\
\pm 1.02 \\
\end{tabular} & $\begin{array}{l}49.22 \\
\pm 0.96 \\
\end{array}$ & $\begin{array}{l}49.14 \pm \\
0.84\end{array}$ & $\begin{array}{r}59.38 \\
\pm 1.27 \\
\end{array}$ & $\begin{array}{r}58.68 \\
\pm 1.65 \\
\end{array}$ & $\begin{array}{l}59.07 \\
\pm 1.31 \\
\end{array}$ & \begin{tabular}{|l}
58.60 \\
\pm 1.31 \\
\end{tabular} & $\begin{array}{l}59.38 \pm \\
1.17\end{array}$ \\
\hline 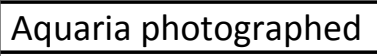 & 2 & & 2 & 2 & 2 & 2 & 1 & 2 & 1 & 2 \\
\hline $\begin{array}{l}\text { Fish in upper aquaria } \\
\text { half (\%) }\end{array}$ & $\begin{array}{l}7.29 \pm \\
11.11\end{array}$ & n.a. & $\begin{array}{l}5.71 \pm \\
10.36\end{array}$ & $\begin{array}{l}10.68 \\
\pm \\
13.24 \\
\end{array}$ & $\begin{array}{l}66.52 \pm \\
11.28 \\
* * * \\
\end{array}$ & $\begin{array}{l}0.14 \pm \\
0.68\end{array}$ & $\begin{array}{l}2.3 \pm \\
3.73 *\end{array}$ & $\begin{array}{l}2.65 \pm \\
3.22 *\end{array}$ & $\begin{array}{l}1.30 \pm \\
2.47\end{array}$ & $\begin{array}{l}79.36 \pm \\
7.19 \\
* * * \\
\end{array}$ \\
\hline $\begin{array}{l}\text { ASMD: total distance } \\
\text { moved }(\mathrm{cm})\end{array}$ & $\begin{array}{l}2700 \\
\pm \\
1405\end{array}$ & $\begin{array}{l}1987 \\
\pm 755\end{array}$ & $\begin{array}{l}2501 \\
\pm 815\end{array}$ & $\begin{array}{l}2252 \\
\pm \\
1353\end{array}$ & $\begin{array}{l}1133 \pm \\
1015 \\
* * *\end{array}$ & $\begin{array}{l}2473 \\
\pm \\
1016\end{array}$ & $\begin{array}{l}1591 \\
\pm \\
1045\end{array}$ & $\begin{array}{l}1792 \\
\pm \\
1320\end{array}$ & $\begin{array}{l}1361 \\
\pm \\
1033 \\
*\end{array}$ & $\begin{array}{l}568 \pm \\
697 * * *\end{array}$ \\
\hline $\begin{array}{l}\text { Aqueous citalopram } \\
\text { concentration }(\mu \mathrm{g} / \mathrm{L})\end{array}$ & $<$ LoD & $\begin{array}{l}0.97 \pm \\
0.20\end{array}$ & $\begin{array}{l}8.30 \pm \\
1.17\end{array}$ & $\begin{array}{l}65.74 \\
\pm 5.77\end{array}$ & $\begin{array}{l}973.98 \\
\pm \\
180.64 \\
\end{array}$ & $<$ LoD & $\begin{array}{l}0.83 \pm \\
0.27\end{array}$ & $\begin{array}{l}8.74 \pm \\
0.48\end{array}$ & \begin{tabular}{|l|}
70.50 \\
\pm \\
11.11 \\
\end{tabular} & $\begin{array}{l}1017.9 \\
7 \quad \pm \\
125.84\end{array}$ \\
\hline $\begin{array}{l}\text { Tissue citalopram } \\
\text { concentration } \quad(\mu \mathrm{g} / \mathrm{g}) \\
\text { (wet weight) }\end{array}$ & $<$ LoD & $\begin{array}{l}0.07 \pm \\
0.014\end{array}$ & $\begin{array}{l}0.69 \pm \\
0.1\end{array}$ & $\begin{array}{l}1.57 \pm \\
0.451\end{array}$ & $\begin{array}{l}55.87 \pm \\
12.972\end{array}$ & $\mid<$ LoD & $\begin{array}{l}0.2 \pm \\
0.042\end{array}$ & $\begin{array}{l}0.97 \pm \\
0.235\end{array}$ & $\begin{array}{l}5.63 \pm \\
2.0\end{array}$ & $\begin{array}{l}142.15 \\
\pm \\
44.961 \\
\end{array}$ \\
\hline
\end{tabular}


Figure 1

Results for brown trout in the ASMD.

Results of total distance moved are shown as boxplot $(A, D, G)$, Results of mean velocity (B, $\mathrm{E}, \mathrm{H})$ and time of no movement $(\mathrm{C}, \mathrm{F}, \mathrm{I})$ are represented as dots, with depicted mean values over time. A-C: Results for brown trout larvae exposed at $7{ }^{\circ} \mathrm{C}, \mathrm{D}-\mathrm{F}$ : Results for brown trout larvae exposed at $11^{\circ} \mathrm{C}, \mathrm{G}-\mathrm{H}$ : Results for juvenile brown trout.
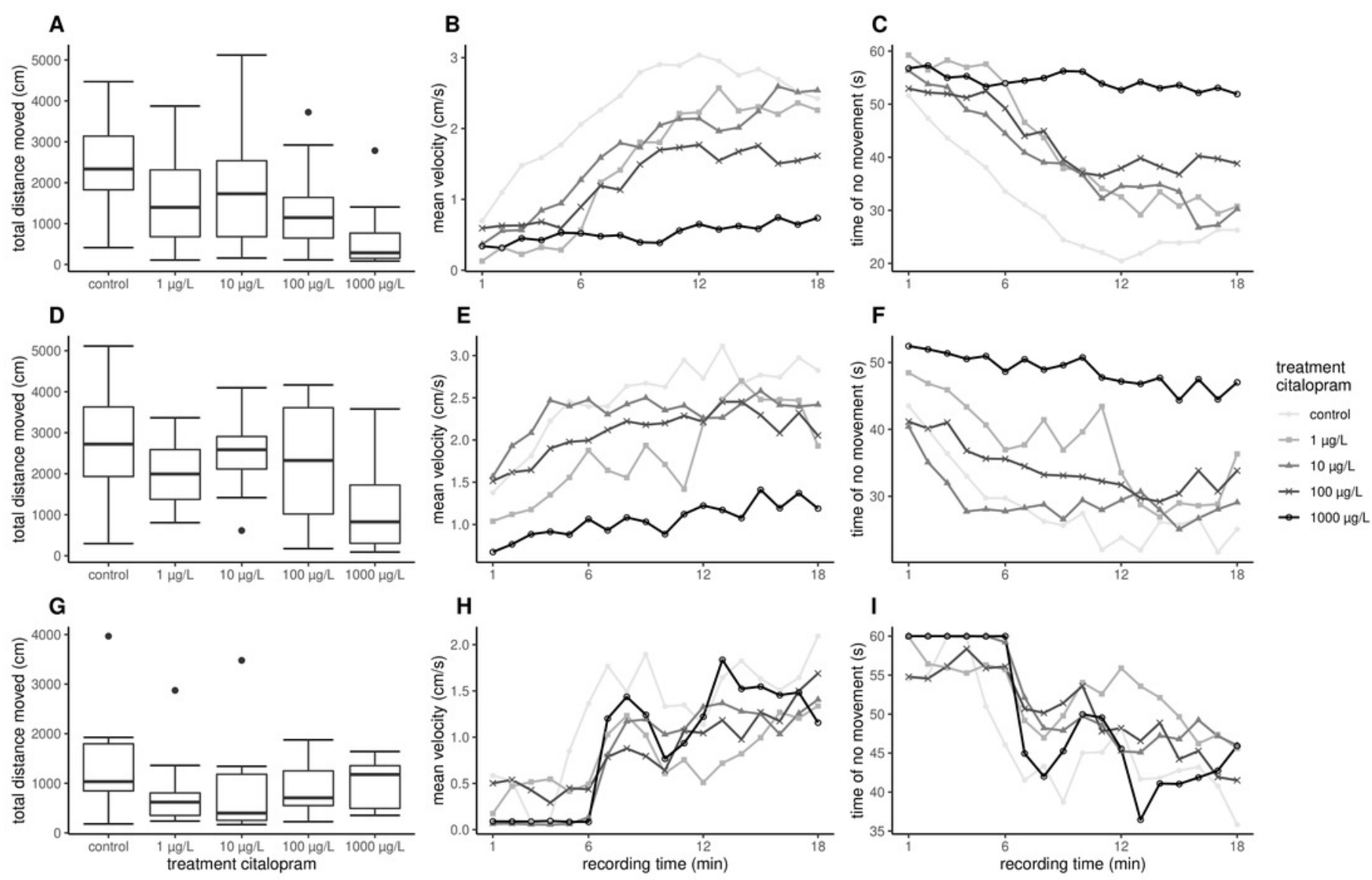


\section{Table 2 (on next page)}

Results for juvenile brown trout exposed to citalopram. <!--[if !supportLineBreakNewLine]--> <!--[endif]-->

Data are shown as arithmetical mean \pm standard deviation. Asterisks indicate significant differences to the respective controls $(* p<0.05 ; * * p<0.01 ; * * p<0.001)$. LoD $=$ limit of detection. 
1 Table 1

2 Results for juvenile brown trout exposed to citalopram.

3 Data are shown as arithmetical mean \pm standard deviation. Asterisks indicate significant differences to the respective controls

$4 \quad\left({ }^{*} p<0.05 ; * * p<0.01 ; * * * p<0.001\right)$. LoD=limit of detection

\begin{tabular}{|c|c|c|c|c|c|}
\hline Treatment $(\mu \mathrm{g} / \mathrm{L})$ & 0 & 1 & 10 & 100 & 1000 \\
\hline Mortality (\%) & $0 \pm 0$ & $0 \pm 0$ & $0 \pm 0$ & $0 \pm 0$ & $0 \pm 0$ \\
\hline Weight (g) & $\begin{array}{c}2.75 \pm \\
0.84\end{array}$ & $\begin{array}{c}2.85 \pm \\
0.85\end{array}$ & $\begin{array}{c}2.86 \pm \\
1.16\end{array}$ & $2.74 \pm 0.92$ & $2.17 \pm 0.53 *$ \\
\hline Length $(\mathrm{cm})$ & $\begin{array}{c}6.41 \pm \\
0.65 \\
\end{array}$ & $\begin{array}{c}6.59 \pm \\
0.61 \\
\end{array}$ & $\begin{array}{c}6.46 \pm \\
0.71 \\
\end{array}$ & $6.50 \pm 0.75$ & $5.93 \pm 0.49 *$ \\
\hline Aquaria photographed & 2 & 2 & 1 & 2 & 2 \\
\hline Fish in upper aquaria half (\%) & $0 \pm 0$ & $0 \pm 0$ & $0 \pm 0$ & $0 \pm 0$ & $\begin{array}{c}25.42 \pm 19.11 \\
* *\end{array}$ \\
\hline ASMD: total distance moved $(\mathrm{cm})$ & $\begin{array}{c}1371 \pm \\
1057\end{array}$ & $\begin{array}{c}847 \pm \\
785\end{array}$ & $\begin{array}{l}878 \pm \\
1004\end{array}$ & $939 \pm 571$ & $980 \pm 473$ \\
\hline Cortisol content in fish extract $(\mathrm{ng} / \mathrm{mL}$ ) & $\begin{array}{c}19.06 \pm \\
14.80\end{array}$ & $\begin{array}{c}15.51 \pm \\
7.48\end{array}$ & $\begin{array}{c}12.50 \pm \\
9.58\end{array}$ & $\begin{array}{c}20.76 \pm \\
15.14\end{array}$ & $23.66 \pm 17.81$ \\
\hline Aqueous citalopram concentration ( $\mu \mathrm{g} / \mathrm{L})$ & $<$ LoD & $\begin{array}{c}1.41 \pm \\
0.22\end{array}$ & $\begin{array}{c}9.20 \pm \\
0.59\end{array}$ & $\begin{array}{c}81.51 \pm \\
2.39\end{array}$ & $\begin{array}{c}864.93 \pm \\
51.54\end{array}$ \\
\hline $\begin{array}{l}\text { Tissue citalopram concentration }(\mu \mathrm{g} / \mathrm{g}) \\
\text { (wet weight) }\end{array}$ & $<$ LoD & $\begin{array}{l}8.2 \pm \\
4.37\end{array}$ & $\begin{array}{l}38.3 \pm \\
30.71\end{array}$ & $\begin{array}{c}340.63 \pm \\
124.74\end{array}$ & $\begin{array}{c}2966.83 \pm \\
1556.77\end{array}$ \\
\hline
\end{tabular}

5 
Figure 2

Cortisol content of juvenile brown trout.

Cortisol content of the fish assessed in the ASMD compared to whose swimming behaviour was not assessed in the ASMD. Results are shown as boxplots. 


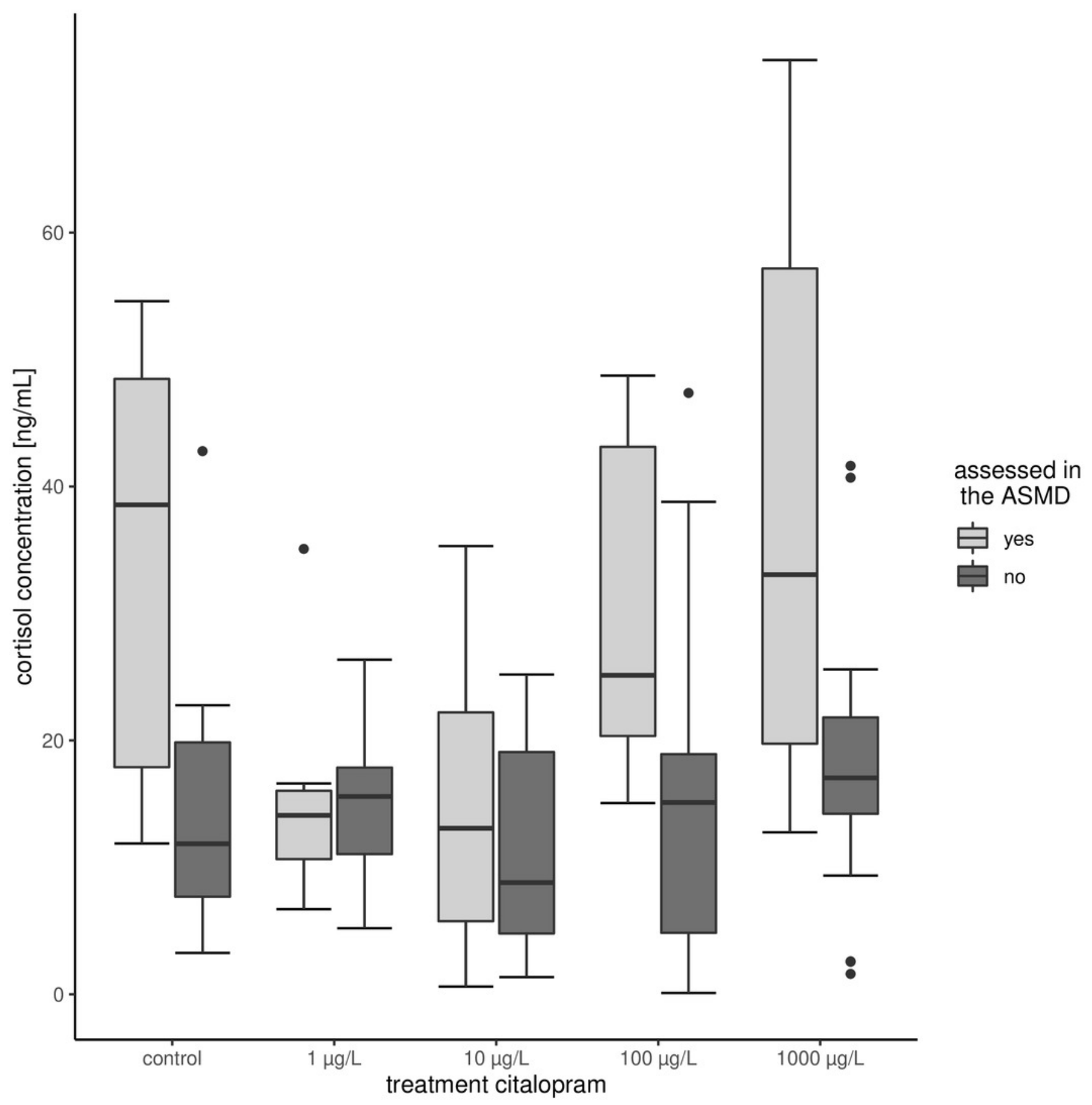

